\title{
What can the neurological manifestations of COVID-19 tell us: a meta-analysis
}

Yuanyuan He, Xiaojie Bai, Tiantian Zhu, Jialin Huang and Hong Zhang*

\begin{abstract}
Background: Covid-19 became a global pandemic in 2019. Studies have shown that coronavirus can cause neurological symptoms, but clinical studies on its neurological symptoms are limited. In this meta-analysis, we aimed to summarize the various neurological manifestations that occurred in COVID-19 patients and calculate the incidence of various neurological manifestations. At the same time, we further explored the mechanism of nervous system injury and prognosis in COVID-19 patients in combination with their nervous system manifestations. This study provides a reference for early clinical identification of COVID-19 nervous system injury in the future, so as to achieve early treatment and reduce neurological sequelae.

Methods: We systematically searched all published English literature related to the neurological manifestations of COVID-19 from January 1, 2020, to April 30, 2021, in Pubmed, Embase, and Cochrane Library. The keywords used were COVID-19 and terminology related to the nervous system performance. All included studies were selected by two independent reviewers using EndNote and NoteExpress software, any disagreement was resolved by consensus or by a third reviewer, and the selected data were then collected for meta-analysis using a random-effects model.

Results: A total of 168 articles $(n=292,693)$ were included in the study, and the meta-analysis showed that the most common neurological manifestations of COVID-19 were myalgia(33\%; $95 \% \mathrm{Cl} 0.30-0.37 ; 1^{2}=99.17 \%$ ), smell impairment(33\%; 95\% Cl 0.28-0.38; $\left.1^{2}=99.40 \%\right)$, taste dysfunction(33\%; 95\% Cl $\left.0.27-0.39 ; 1^{2}=99.09 \%\right)$, altered mental status(32\%; 95\% Cl 0.22-0.43; $\left.1^{2}=99.06 \%\right)$, headache $\left(29 \% ; 95 \% \mathrm{Cl} 0.25-0.33 ; I^{2}=99.42 \%\right)$, encephalopathy $(26 \% ; 95 \% \mathrm{Cl}$ $\left.0.16-0.38 ;\left.\right|^{2}=99.31 \%\right)$, alteration of consciousness $\left(13 \% ; 95 \% \mathrm{Cl} 0.08-0.19 ;\left.\right|^{2}=98.10 \%\right)$, stroke $(12 \% ; 95 \% \mathrm{Cl} 0.08-0.16$; $\left.\mathrm{I}^{2}=98.95 \%\right)$, dizziness $\left(10 \% ; 95 \% \mathrm{Cl} 0.08-0.13 ; \mathrm{l}^{2}=96.45 \%\right)$, vision impairment $\left(6 \% ; 95 \% \mathrm{Cl} 0.03-0.09 ;\left.\right|^{2}=86.82 \%\right)$, intracerebral haemorrhage $\left(5 \% ; 95 \% \mathrm{Cl} 0.03-0.09 ; I^{2}=95.60 \%\right)$, seizure $\left(4 \% ; 95 \% \mathrm{Cl} 0.02-0.05 ;\left.\right|^{2}=98.15 \%\right)$, encephalitis $(2 \%$; $\left.95 \% \mathrm{Cl} 0.01-0.03 ; \mathrm{I}^{2}=90.36 \%\right)$, Guillan-Barré Syndrome (GBS) (1\%; 95\%Cl $\left.0.00-0.03 ; \mathrm{I}^{2}=89.48 \%\right)$.

Conclusions: Neurological symptoms are common and varied in Covid-19 infections, and a growing number of reports suggest that the prevalence of neurological symptoms may be increasing. In the future, the role of COVID-19 neurological symptoms in the progression of COVID-19 should be further studied, and its pathogenesis and assessment methods should be explored, to detect and treat early neurological complications of COVID-19 and reduce mortality.
\end{abstract}

Keywords: COVID-19, SARS-CoV-2, Neurologic manifestations, The prevalence rate

*Correspondence: zhanghong20070703@163.com Department of Emergency Medicine, The First Affiliated Hospital of Anhui Medical University, 218 jixi road, shushan district, Hefei, Anhui, China

\section{Introduction}

At the end of December 2019, an epidemic of COVID19 occurred in Wuhan, Hubei Province, China. As the epidemic has spread, cases have been found in many countries. At the time of writing, it has spread to more than 200 countries and regions, with a total original author(s) and the source, provide a link to the Creative Commons licence, and indicate if changes were made. The images or other third party material in this article are included in the article's Creative Commons licence, unless indicated otherwise in a credit line to the material. If material is not included in the article's Creative Commons licence and your intended use is not permitted by statutory regulation or exceeds the permitted use, you will need to obtain permission directly from the copyright holder. To view a copy of this licence, visit http://creativecommons.org/licenses/by/4.0/. The Creative Commons Public Domain Dedication waiver (http://creativeco mmons.org/publicdomain/zero/1.0/) applies to the data made available in this article, unless otherwise stated in a credit line to the data. 
of 187,637,579 confirmed cases and 4,066,292 death. Coronavirus has caused two fatal outbreaks in the past, the first in China in 2003, with a 10 percent mortality rate; The second outbreak was Middle East Respiratory Syndrome (MERS) in Saudi Arabia in 2012, with a mortality rate of $35 \%$ [1, 2]. Novel Coronavirus was named severe acute respiratory syndrome coronavirus Type 2 (SARS-COV-2). Sars-Cov-2 is a single-stranded RNA coronavirus, belonging to the same -coronavirus branch as SARS-COV and MERS-CoV. Its genome sequence is $89.1 \%$ similar to the nucleotide sequence of a group of SARS-like coronaviruses. Studies have found that the viral structure and receptor binding domain of SARS-COV-2 is similar to that of SARS-COV, and both of them enter human cells by binding to ACE2 receptors $[3,4]$. To evaluate the genetic variation of SARSCOV-2, 86 complete or nearly complete genomes were genetically analyzed, and many mutations and deletions were found in both coding and non-coding regions [5]. At present, the biological characteristics and genetic variation of SARS-COV-2 are still not very clear and deserve further study.

Although COVID-19 is typically characterized by respiratory symptoms, numerous clinical studies have shown that patients infected with SARS-COV-2 are associated with acute injuries to external pulmonary organs, including the heart, digestive tract, liver, kidney, and nervous system $[6,7]$. More and more clinical evidence indicates that SARS-COV-2 may invade the central nervous system. A retrospective analysis of 214 patients with COVID-19 found that 78 (36.4\%) had nervous system involvement, and $28.2 \%$ of them had severe central nervous system injury [8]. Studart-Neto A et al. retrospectively analyzed 1208 patients with COVID-19 and found that $89(7.4 \%)$ presented neurological manifestations, including encephalopathy (44.4\%), stroke (16.7\%), epilepsy (9.0\%), neuromuscular disease (5.6\%), another acute brain injury (3.4\%), and other mild non-specific diseases (11.2\%) [9]. Takeshi et al. detected SARS-COV-2 RNA in cerebrospinal fluid specimens, providing direct evidence for the nervous invasiveness of SARS-COV-2 [10]. There are three main types of COVID-19 nervous system involvement: (1) central nervous system involvement, such as dizziness, headache, disturbance of consciousness, acute cerebrovascular disease, and epilepsy; (2) peripheral nervous system involvement, including anosmia, decreased taste, decreased vision, and neuralgia; (3) skeletal muscle injury [11, 12].COVID-19 possible mechanisms include: nerve injury by angiotensin-converting enzyme (ACE2) receptor function, blood and break through the blood-brain barrier, through the way such as the olfactory nerve attack the nervous system $[13,14]$.
Since nervous system manifestations are an important part of COVID-19 patients' clinical manifestations, early detection and treatment of nerve injury in COVID-19 patients is of great significance for their prognosis and reduction of neurological sequelae. This study aims to further summarize the incidence and characteristics of various nervous system manifestations in COVID-19 patients, and explore the mechanism and prognosis of nervous system injury in combination with nervous system manifestations, so as to provide positive clinical significance for better epidemic prevention and control and clinical diagnosis and treatment in the future.

\section{Methods}

\section{Search strategy and research selection}

We searched the following electronic databases for literature published between 1 January 2020 and April 30, 2021: Pubmed, Embase and the Cochrane Library. The search terms used include: ((severe acute respiratory syndrome coronavirus 2) OR (SARS-CoV-2) OR (2019$\mathrm{nCoV}$ ) OR (2019 novel coronavirus) OR (COVID-19) OR (coronavirus) OR (novel coronavirus pneumonia) OR (NCP)) AND ((neurologic manifestations) OR (neurological manifestations) OR (neurologic manifestation) OR (neurologic signs and symptoms) OR (neurological manifestation) OR (neurologic deficits) OR (neurologic deficit) OR (neurologic symptoms) OR (neurologic symptom) OR (neurologic findings) OR (neurologic finding) OR (neurologic signs) OR (neurologic sign) OR (neurologic dysfunction) OR (neurologic dysfunctions) OR (nervous system diseases) OR (nervous system disease) OR (neurologic disorders) OR (neurologic disorder) OR (neurological disorders) OR (neurological disorder) OR (nervous system disorders) OR (nervous system disorder) OR (neurological complication) OR (neurological complications) OR (nerve function injury)).

\section{Inclusion and exclusion criteria}

The inclusion criteria for this study are as follows: all English literature from 1 January 2020 solstices 30 April 2021 that has been published reporting neurological manifestations of COVID-19 patients. Studying types include case-control studies, cohort studies, cross-sectional studies, and case series. Only those subjects who were diagnosed with SARS-COV-2 infection by realtime reverse transcription-polymerase chain reaction or by high-throughput sequencing of swab samples were included in the study. Only those studies whose results included specific neurological manifestations were included.

Exclusion criteria included: (1) no clinical manifestations of related neurological symptoms and lack relevant data; (2) Age $<18$ years old; (3) Repeated studies; (4) 
Editorials, reviews, systematic reviews, meta-analyses, comment, animal studies, postmortem studies, etc. (5) Documents not written in English.

\section{Data extraction and quality assessment}

A comprehensive and rigorous review of all literature retrieved was conducted by two independent study members according to inclusion and exclusion criteria, and any disagreement between reviewers was determined by consultation between the two or by a third investigator. Extracting data from each study include the first author's name, year, country, research design, time and duration, participants details (gender, age, the overall sample size and specific symptoms of patients number) and neurologic manifestations, such as headache, dizziness, altered mental status, stroke, intracerebral hemorrhage, seizure, myalgia, smell impairment, taste dysfunction, vision impairment, alteration of consciousness, encephalitis, encephalopathy and Guillan-Barré Syndrome (GBS).

The STROBE Statement was used to evaluate the quality of the included studies. It consists of 22 projects and is used to evaluate six main components, including title and abstract, Introduction, Methods, Results, Discussion, and other information. Quality evaluations were conducted by two independent researchers, and any differences between them were resolved by discussion or by the intervention of a third researcher.

\section{Statistical analysis}

Our study synthesizes the results of several similar studies to provide a quantitative summary. The extracted data details and instructions are presented in tables and figures. We used Stata (version 15.1) for the meta-analysis. $\mathrm{I}^{2}$ was calculated to assess the level of heterogeneity and can be divided into four categories: maybe unimportant (0-40\%), may represent moderate heterogeneity (30$60 \%$, may represent significant heterogeneity (50-90\%) and significant heterogeneity $(75-100 \%)$. In this study, a fixed-effect model or random-effect model was used to calculate the comprehensive prevalence rate and $95 \%$ confidence interval. When there was no heterogeneity, the fixed effect model was selected; when there was heterogeneity, a random effect model was selected. Forest maps are used to visually indicate the magnitude of the effects that the study summarizes and their $95 \%$ confidence intervals. Funnel plot and Egger's test were used to assess the publication bias of all literature, and $\mathrm{P}<0.05$ was considered statistically significant.

\section{Results}

A total of 8812 studies were selected from the database, including 5789 in Pubmed, 2971 in Embase, and 52 in the Cochrane Library. After eliminating duplicate studies $(\mathrm{n}=1916), 6896$ studies met the preliminary screening criteria based on titles and abstracts. After excluding review, mata analysis, case report, age $<18$, animal experiment and literature with inconsistent research contents $(\mathrm{n}=6483)$, the remaining 413 articles were screened according to the inclusion and exclusion criteria. After the full-text screening, 168 articles $(\mathrm{N}=292,693)$ were included in the meta-analysis. Figure 1 showed the Study Flow Diagram. All of the studies were published in 2020 and 2021. Among the included studies, 6 studies were case-control studies, 10 studies were case series, 13 were cohort studies, and 25 were cross-sectional studies.104 retrospective studies, 36 prospective studies and 29 multicenter studies were included. Major countries included were 29 studies in the USA, 20 in Italy, 17 in Spain, 15 in France, 15 in China and 12 in Turkey. Table 1 showed the details and characteristics of the included studies.

Myalgia(33\%; 95\%CI $\left.\quad 0.30-0.37 ; \quad \mathrm{I}^{2}=99.17 \%\right) \quad(86$ studies), smell impairment(33\%; 95\%CI $0.28-0.38$; $\left.\mathrm{I}^{2}=99.40 \%\right) \quad(106$ studies), taste dysfunction(33\%; $95 \%$ CI $0.27-0.39 ; \mathrm{I}^{2}=99.09 \%$ ) (80 studies) and altered mental status(32\%; 95\%CI $\left.0.22-0.43 ; \quad \mathrm{I}^{2}=99.06 \%\right) \quad(18$ studies) were the most common neurological manifestations of COVID-19. Headache(29\%; 95\%CI 0.25-0.33; $\left.\mathrm{I}^{2}=99.42 \%\right) \quad$ (123 studies), encephalopathy(26\%; 95\%CI $0.16-0.38 ; \mathrm{I}^{2}=99.31 \%$ ) (23 studies), alteration of consciousness $\left(13 \% ; \quad 95 \%\right.$ CI $\left.\quad 0.08-0.19 ; \quad I^{2}=98.10 \%\right) \quad(19$ studies), stroke(12\%; 95\%CI 0.08-0.16; $\left.\mathrm{I}^{2}=98.95 \%\right) \quad(47$ studies), dizziness(10\%; 95\%CI $\left.0.08-0.13 ; \mathrm{I}^{2}=96.45 \%\right)$ (50 studies), vision impairment $(6 \%$; 95\% CI $0.03-0.09$; $\left.\mathrm{I}^{2}=86.82 \%\right)$ (14 studies), intracerebral haemorrhage(5\%; 95\%CI $\left.0.03-0.09 ; \mathrm{I}^{2}=95.60 \%\right) \quad(21$ studies $)$ and seizure $\left(4 \%\right.$; 95\%CI $0.02-0.05 ; \mathrm{I}^{2}=98.15 \%$ ) (47 studies) were the next most common. The less common neurological manifestations were encephalitis(2\%; 95\%CI $0.01-0.03$; $\left.\mathrm{I}^{2}=90.36 \%\right)$ (14 studies) and Guillan-Barré Syndrome (GBS) (1\%; 95\%CI 0.00-0.03; I ${ }^{2}=89.48 \%$ ) (12 studies).

In all the included literature, 16 studies grouped and analyzed the neurological characteristics according to the severity of COVID-19. Through meta-analysis, we concluded that there was no significant difference in the incidence of headache $\left(16 \% ; 95 \%\right.$ CI $0.11-0.22 ; \mathrm{I}^{2}=94.05 \%$ VS $16 \% ; 95 \%$ CI $\left.0.10-0.23 ; I^{2}=97.77 \%\right)$ between the severe group and the non-severe group, and the incidence of dizziness $\left(12 \% ; 95 \%\right.$ CI $0.07-0.18 ; \mathrm{I}^{2}=88.28 \% \mathrm{VS}$ $9 \% ; 95 \%$ CI $\left.0.04-0.16 ; \mathrm{I}^{2}=96.05 \%\right)$ and seizure $(3 \% ; 95 \% \mathrm{CI}$ $0.01-0.06 ; \quad I^{2}=83.80 \% \quad$ VS $\quad 1 \% ; 95 \%$ CI $\quad 0.00-0.03$; $\left.\mathrm{I}^{2}=86.05 \%\right)$ was higher, while myalgia $(21 \% ; 95 \% \mathrm{CI}$ $0.13-0.29 ; \quad \mathrm{I}^{2}=97.82 \% \quad$ VS $\quad 24 \% ; 95 \% \mathrm{CI} \quad 0.16-0.32$; $\left.\mathrm{I}^{2}=98.39 \%\right)$, smell impairment $(8 \% ; 95 \% \mathrm{CI} \quad 0.05-0.13$; $\mathrm{I}^{2}=87.77 \%$ VS $\left.13 \% ; 95 \% \mathrm{CI} 0.08-0.18 ; \mathrm{I}^{2}=92.34 \%\right)$ and taste dysfunction $\left(9 \% ; 95 \%\right.$ CI $0.05-0.14 ; \quad \mathrm{I}^{2}=90.24 \%$ VS $14 \% ; 95 \%$ CI $\left.0.10-0.20 ; \mathrm{I}^{2}=93.21 \%\right)$ were less. Table 2 


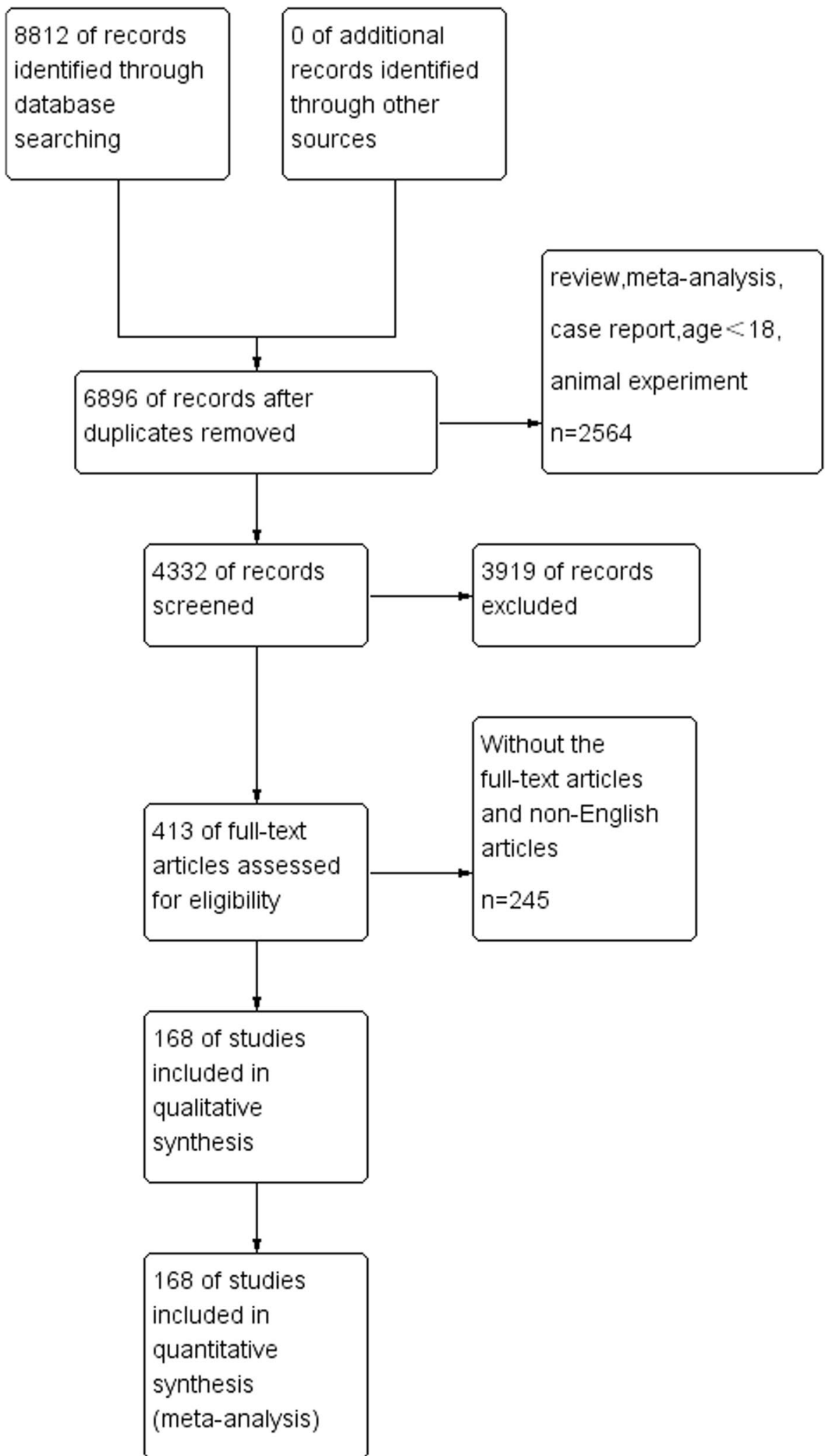

Fig. 1 The Study flow Diagram 


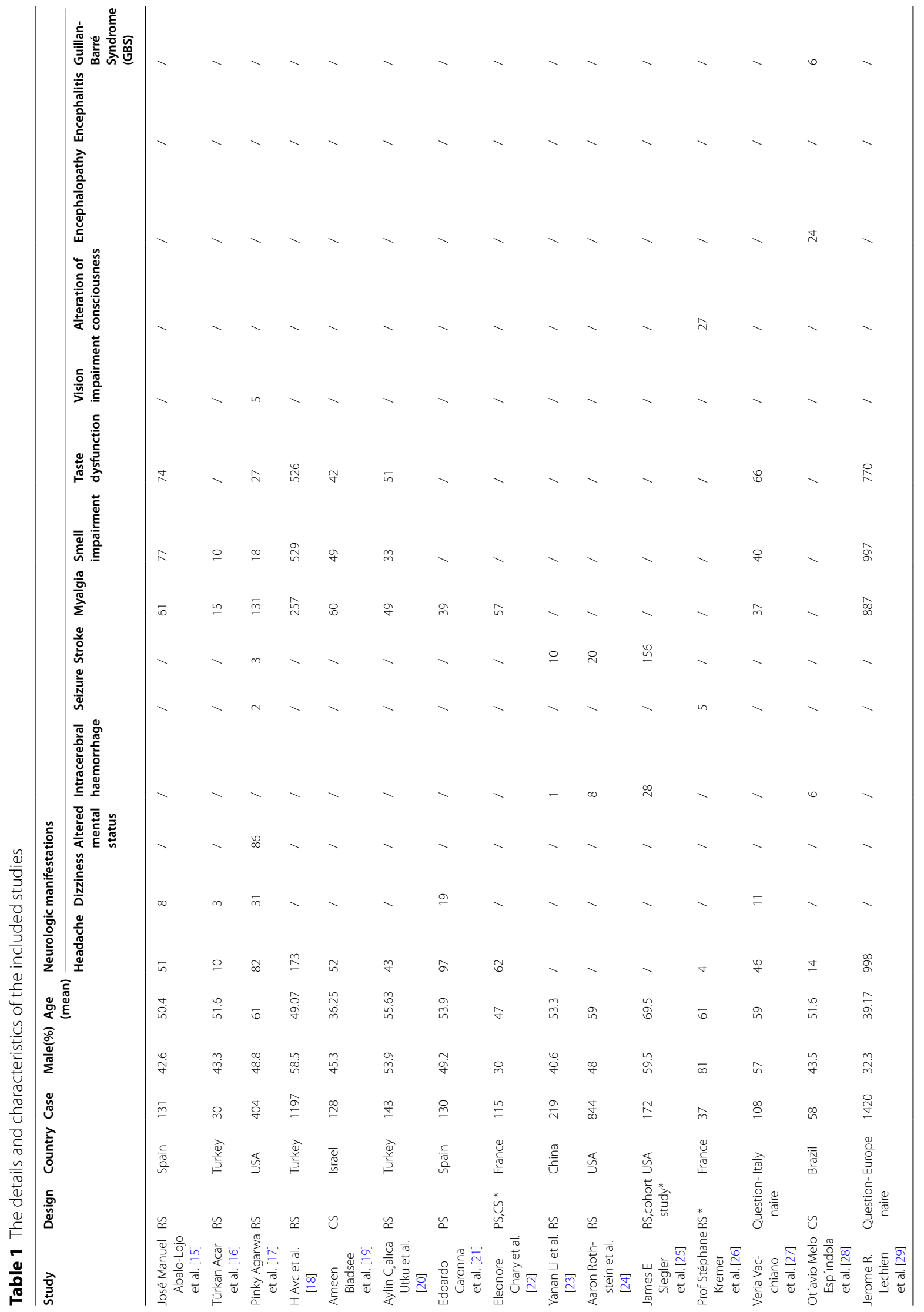




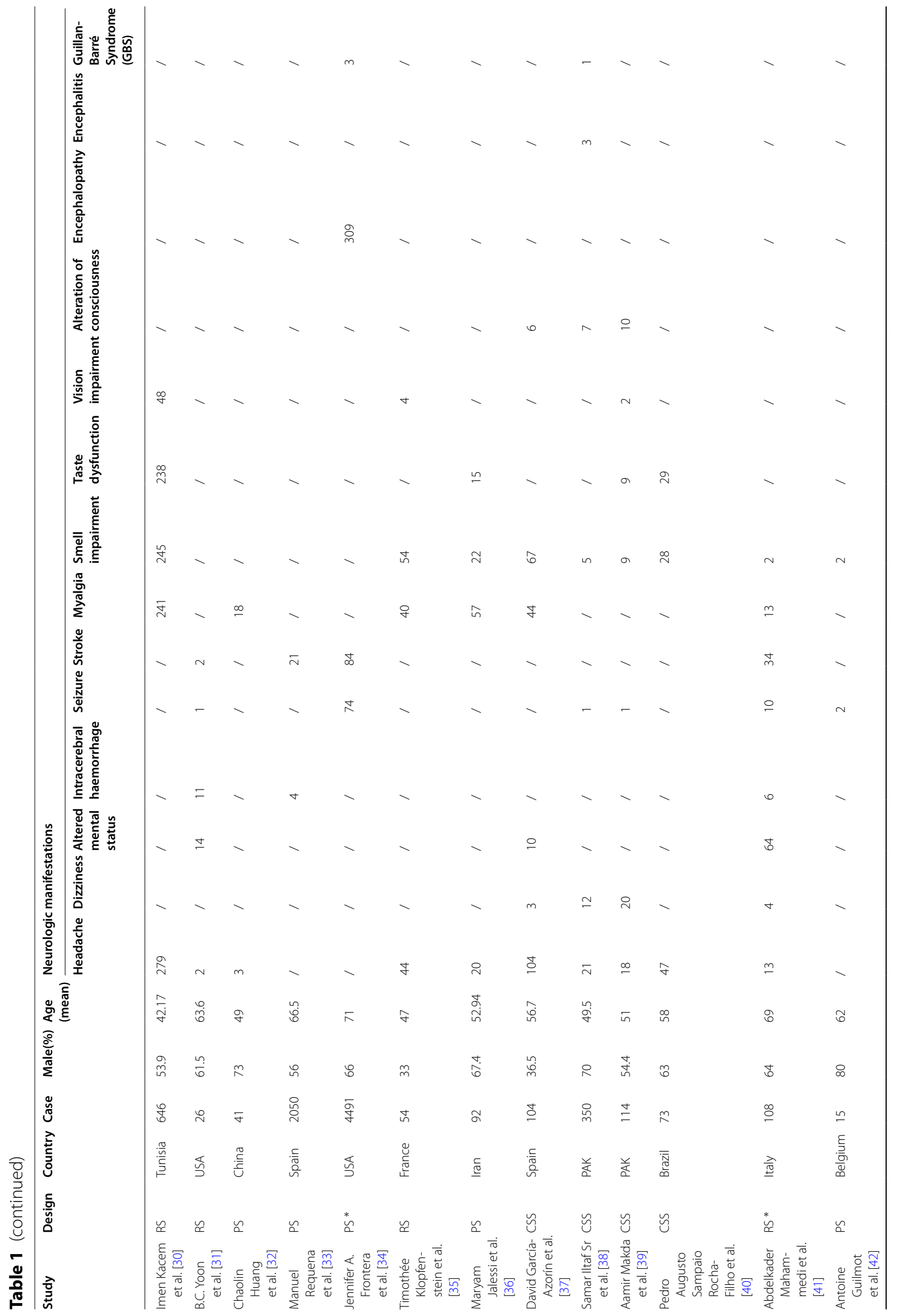


He et al. J Transl Med ～～(2021) 19:363

Page 7 of 35

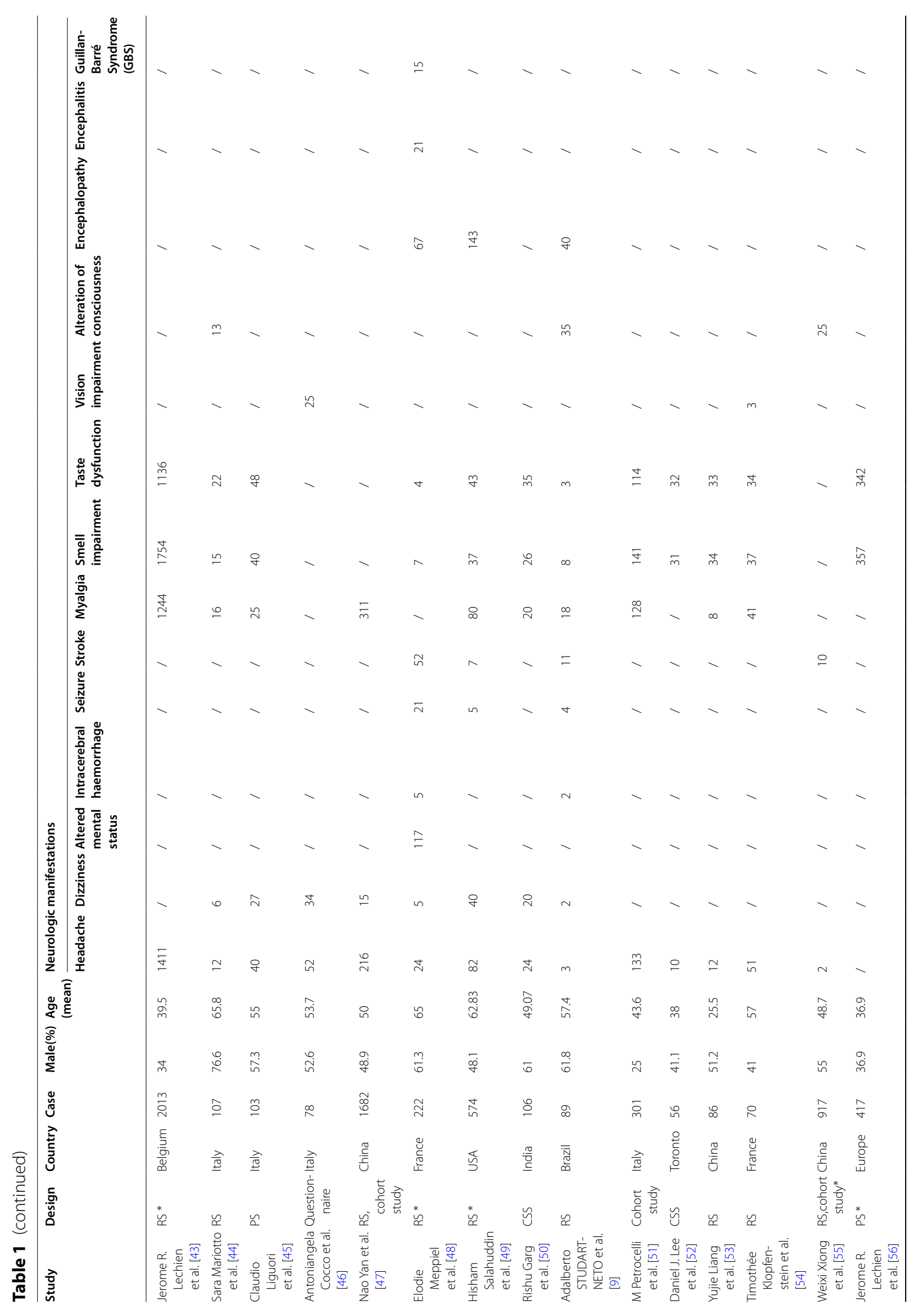




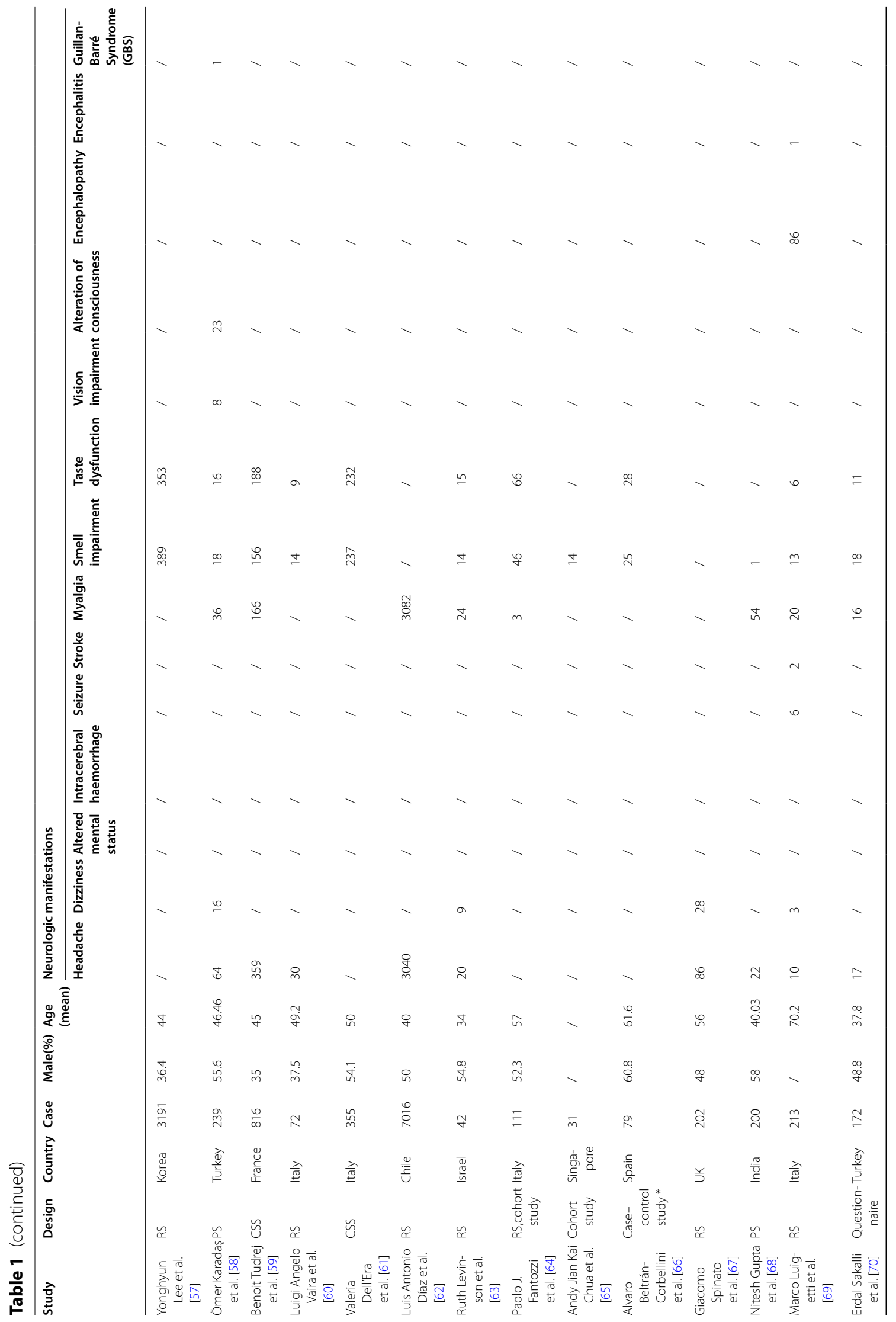


He et al. J Transl Med ～～(2021) 19:363

Page 9 of 35

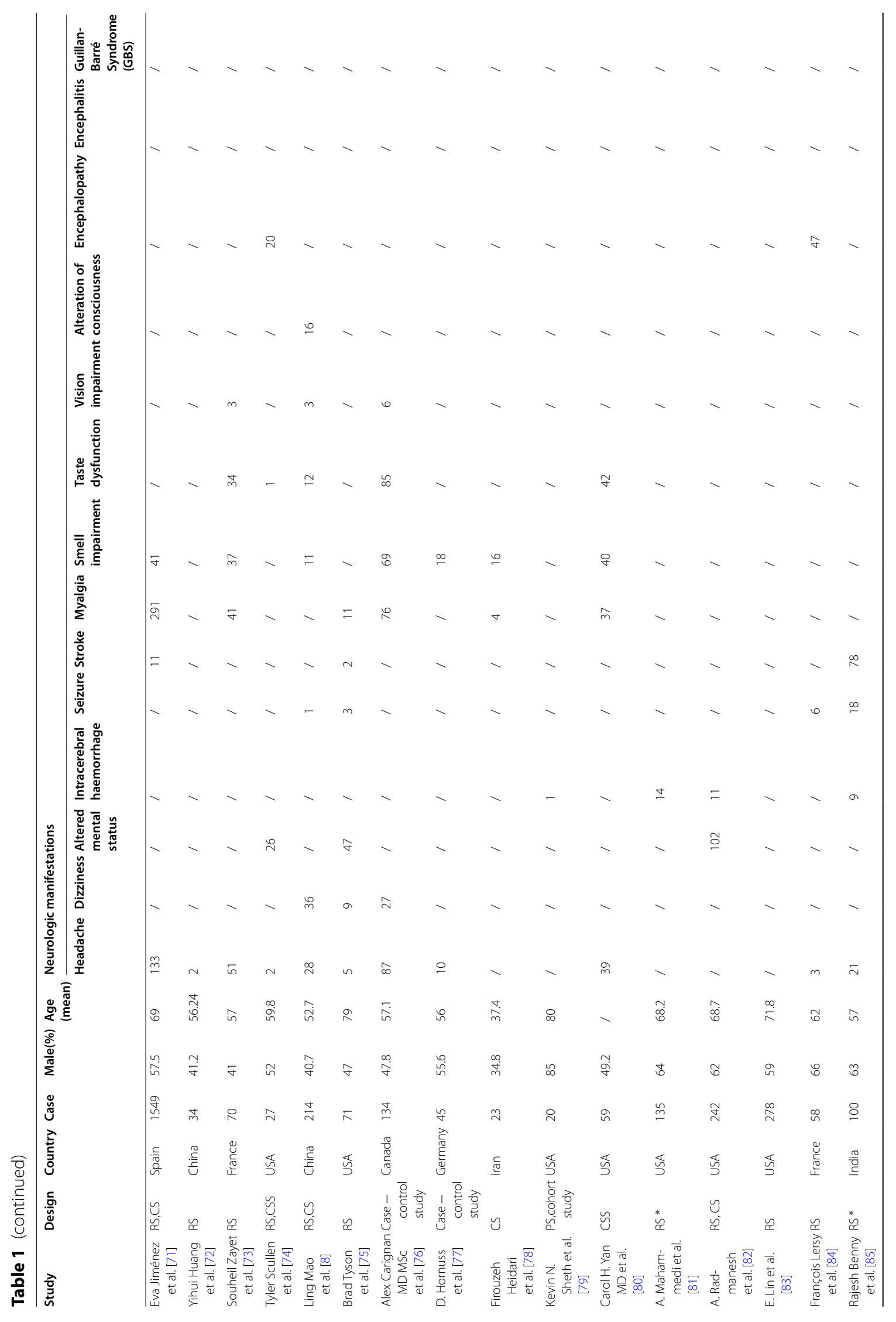




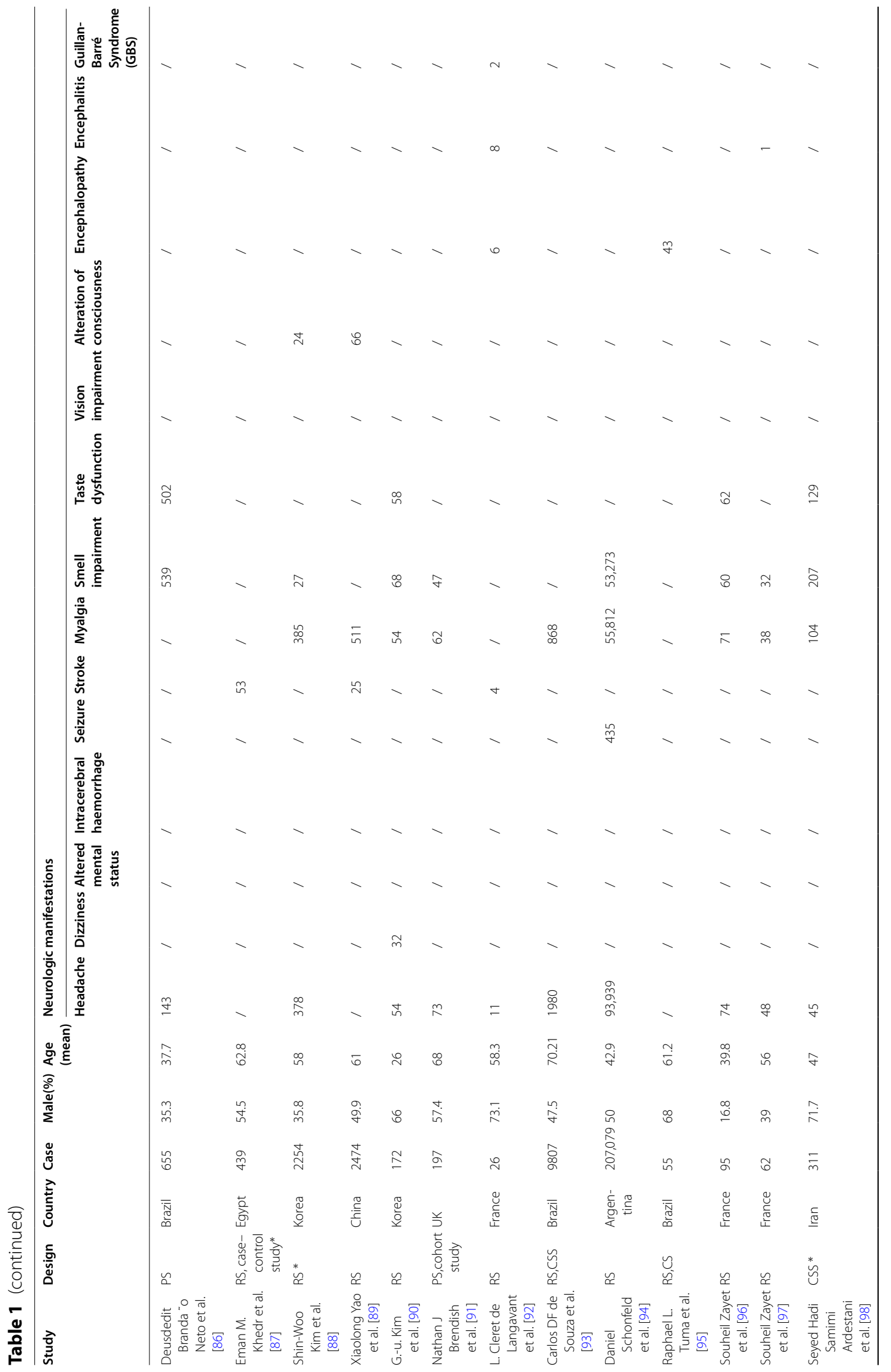




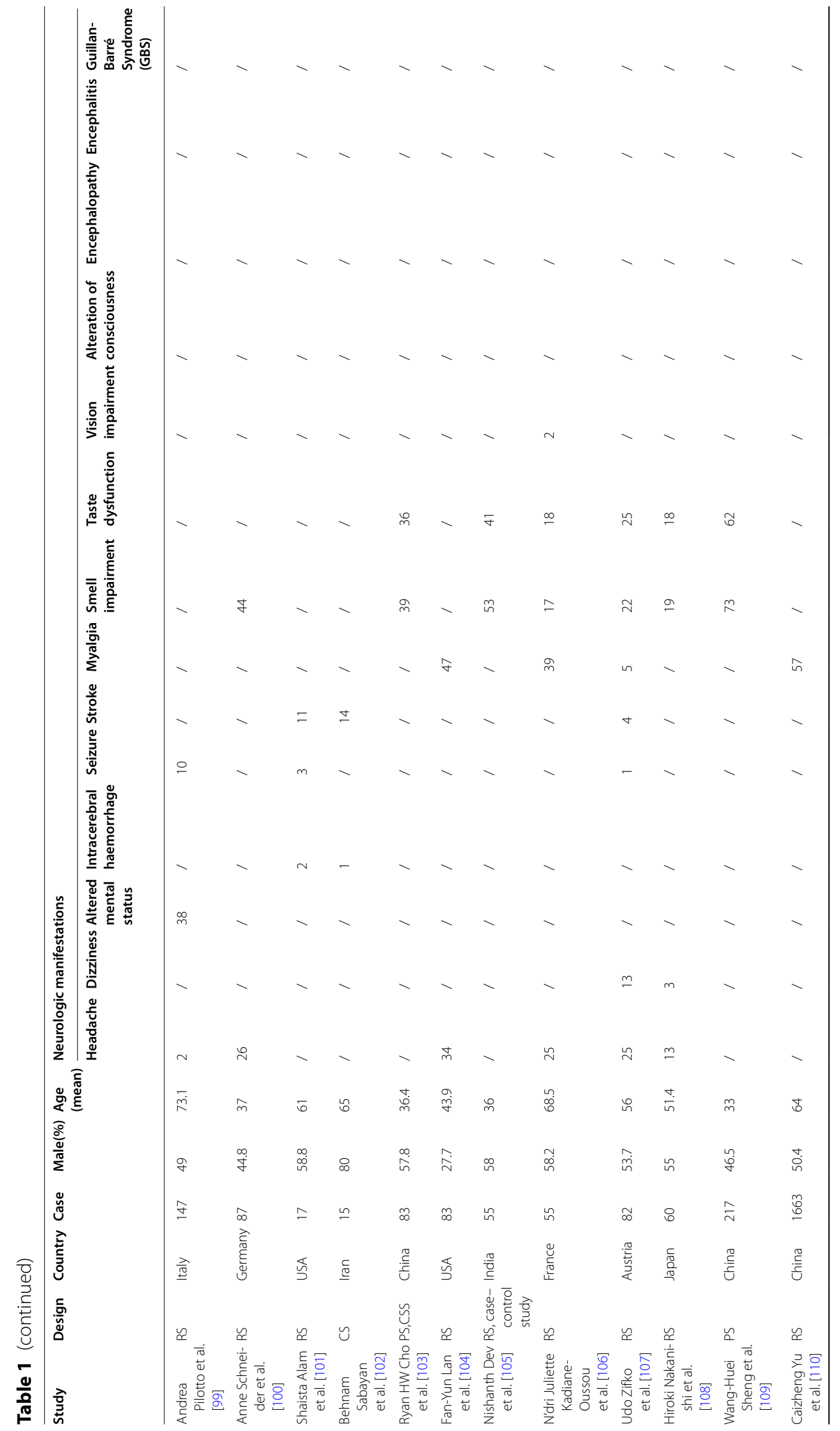




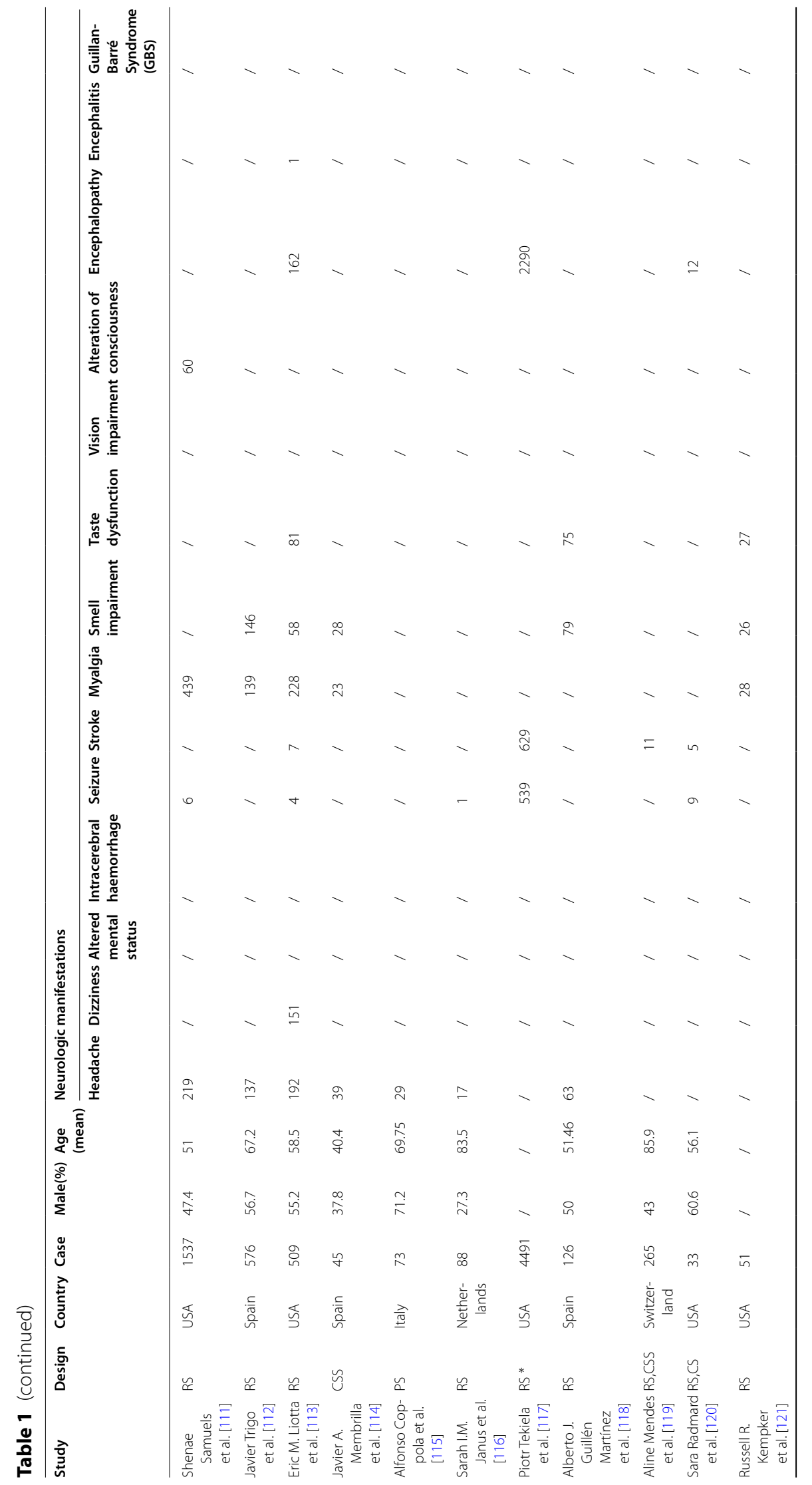


He et al. J Transl Med ～(2021) 19:363

Page 13 of 35

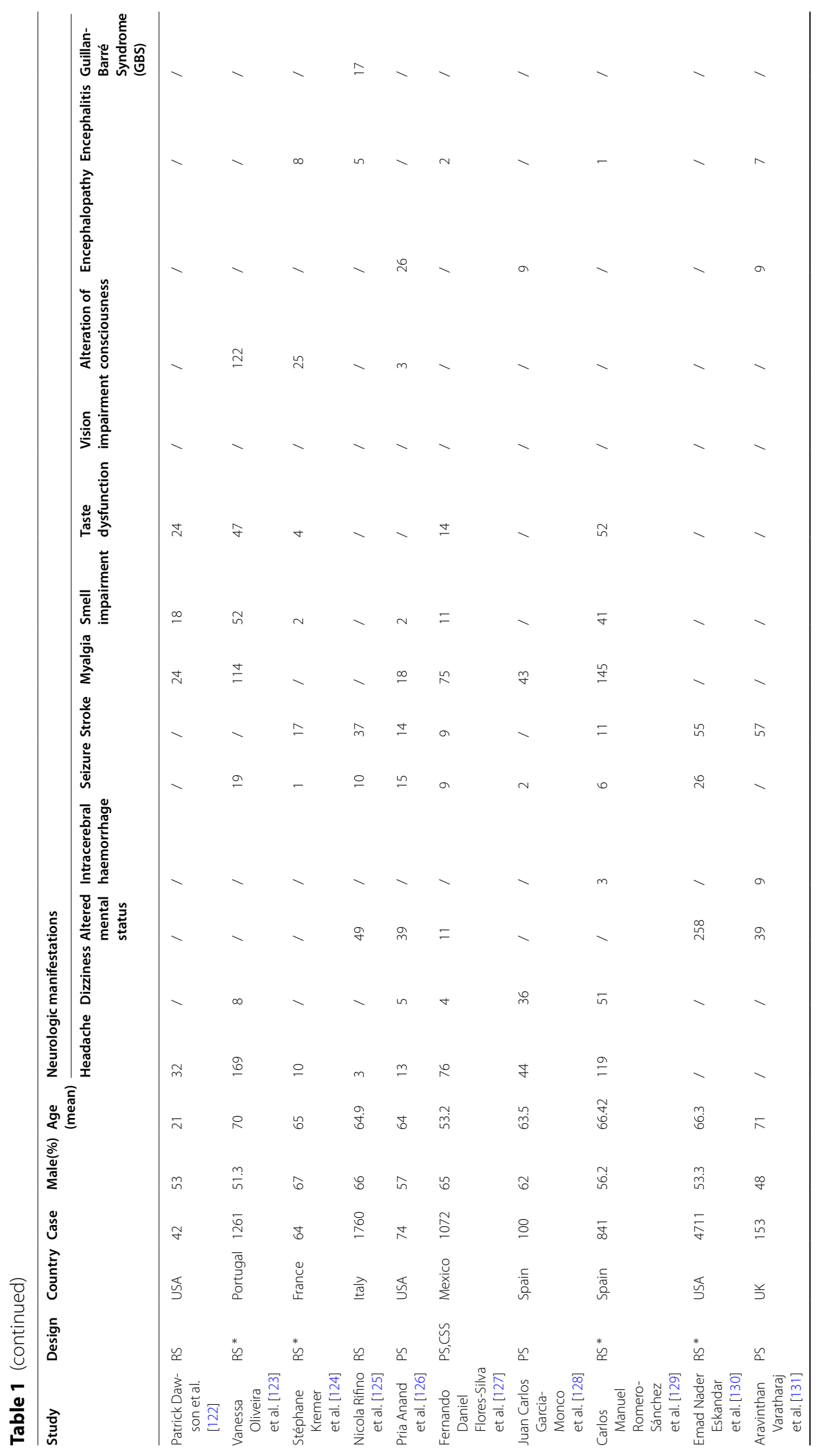




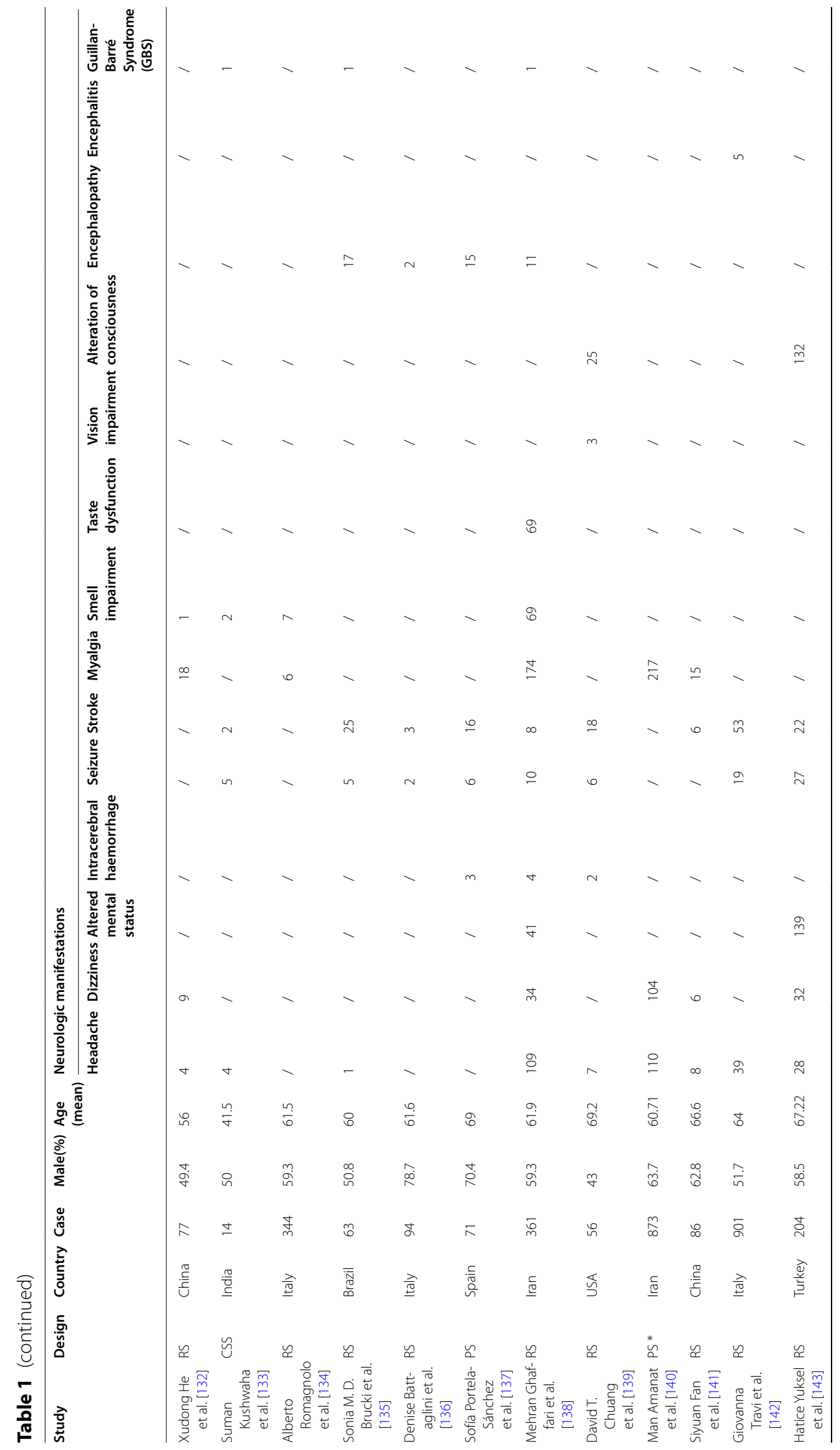




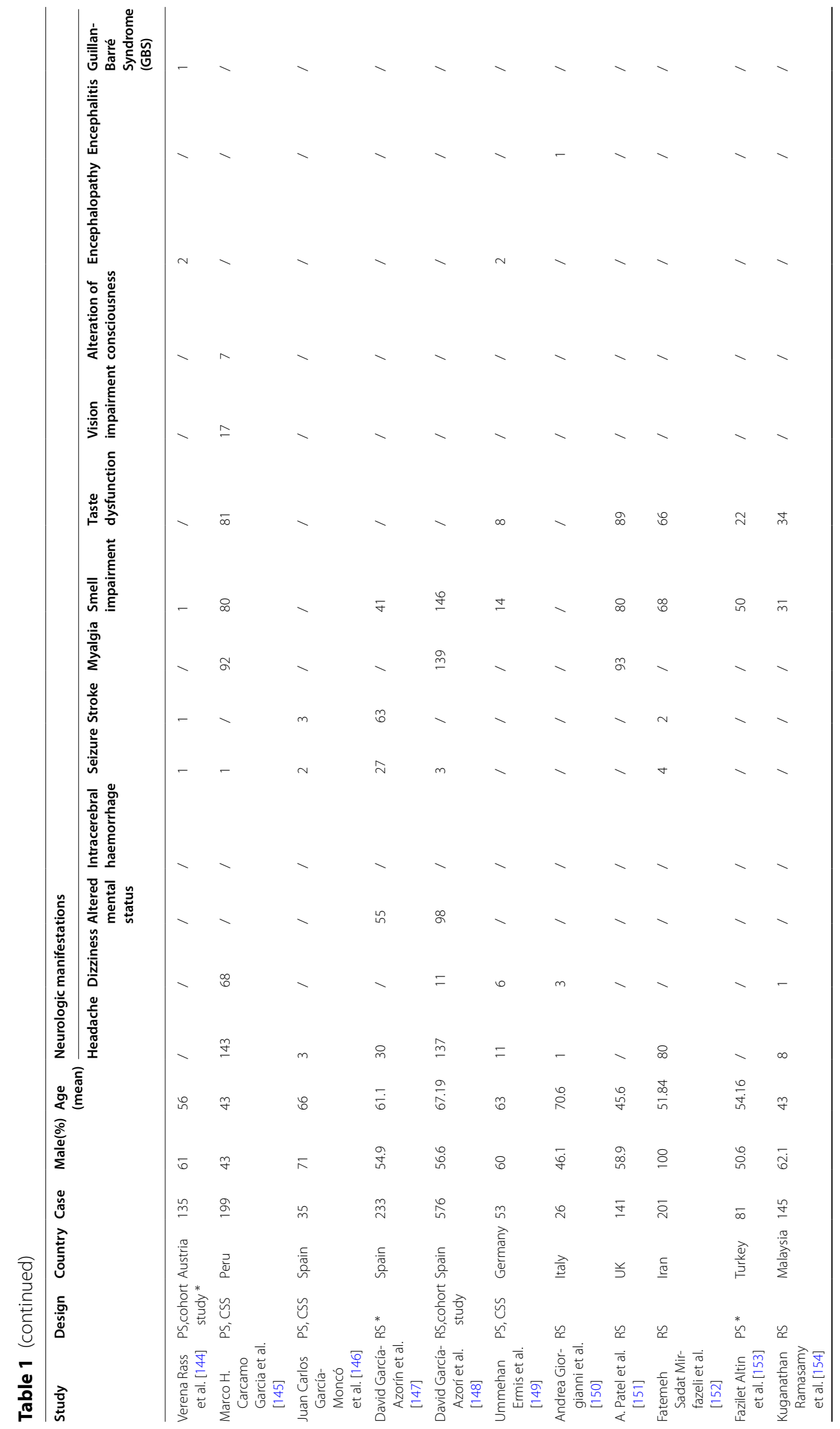




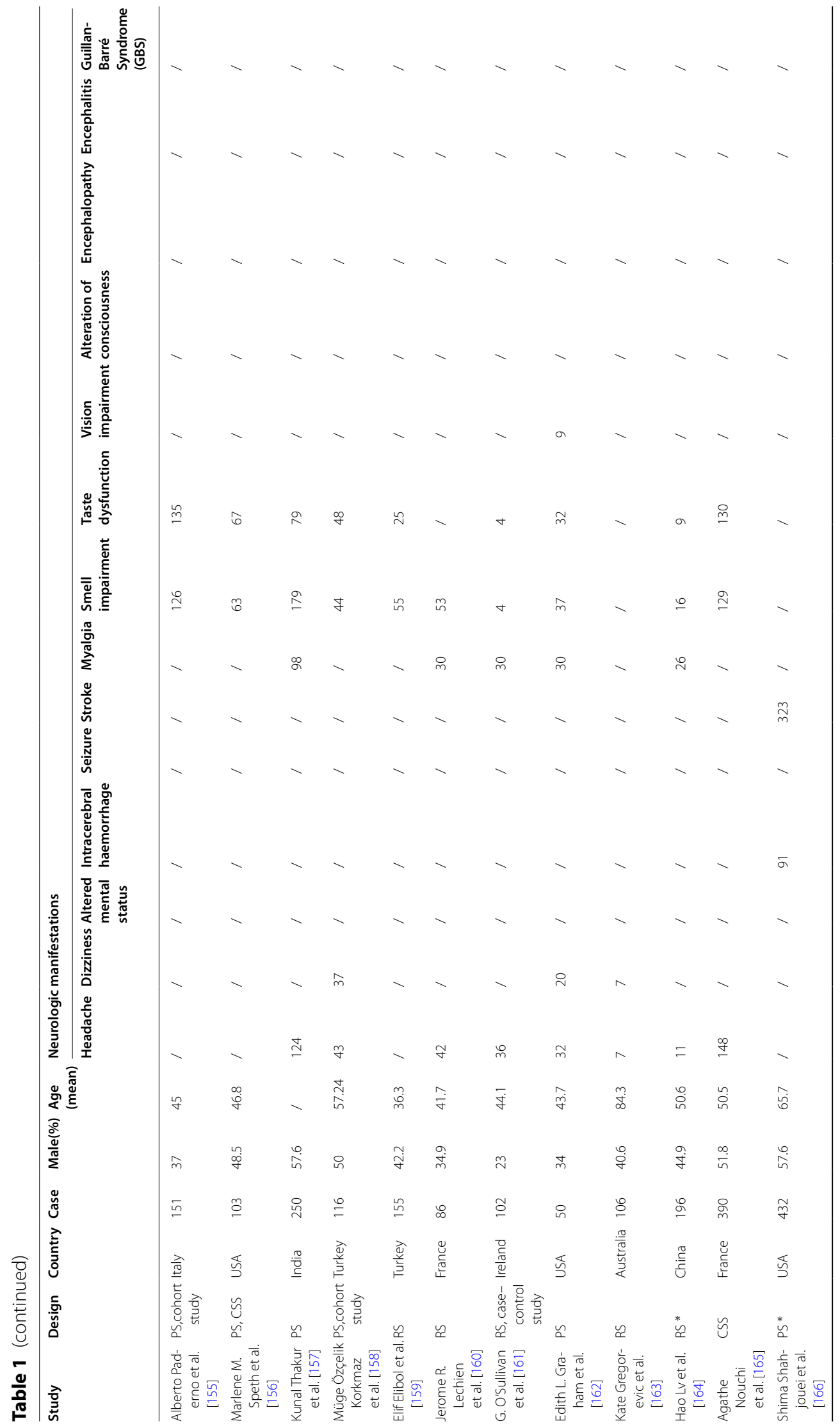




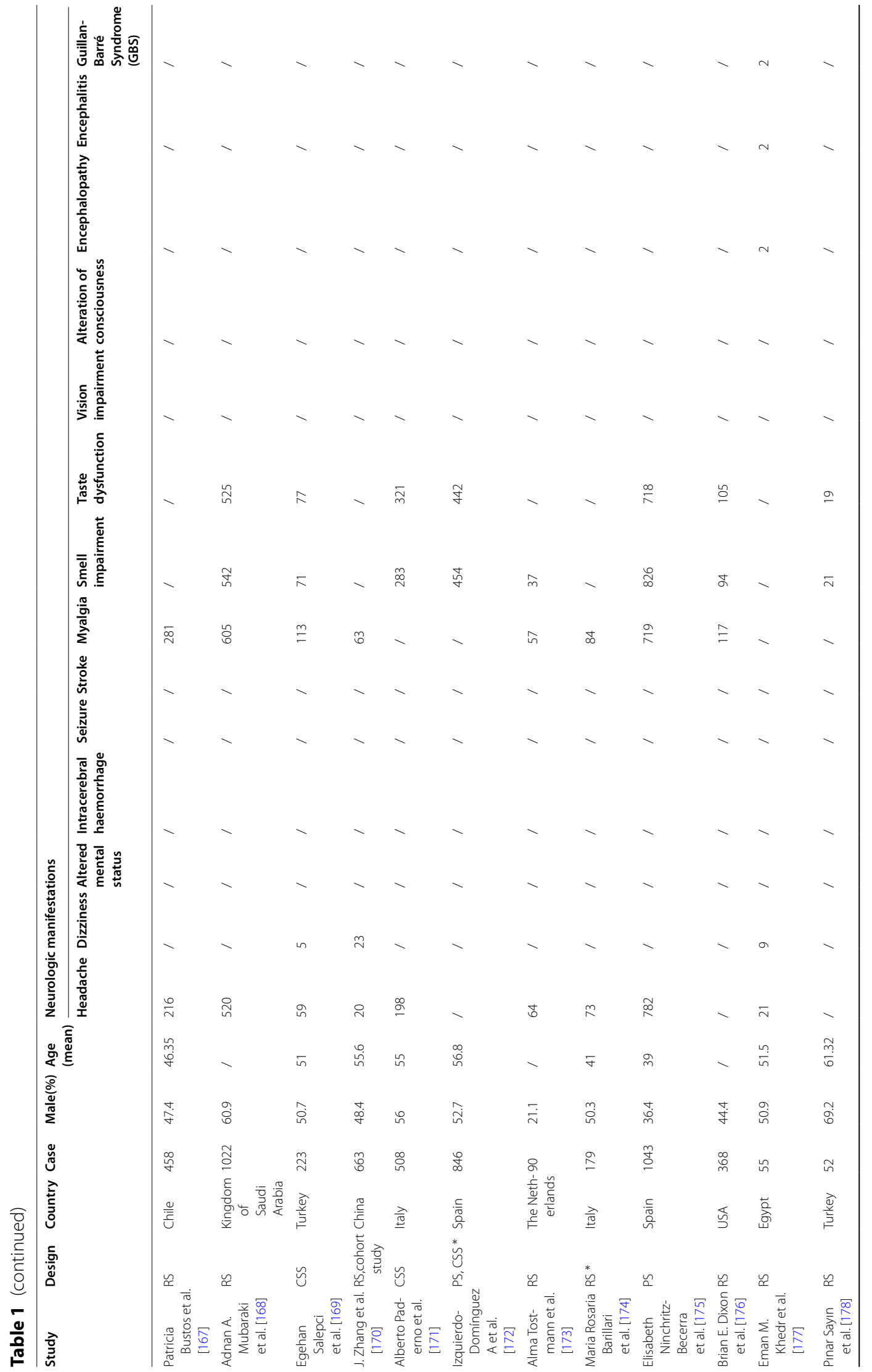




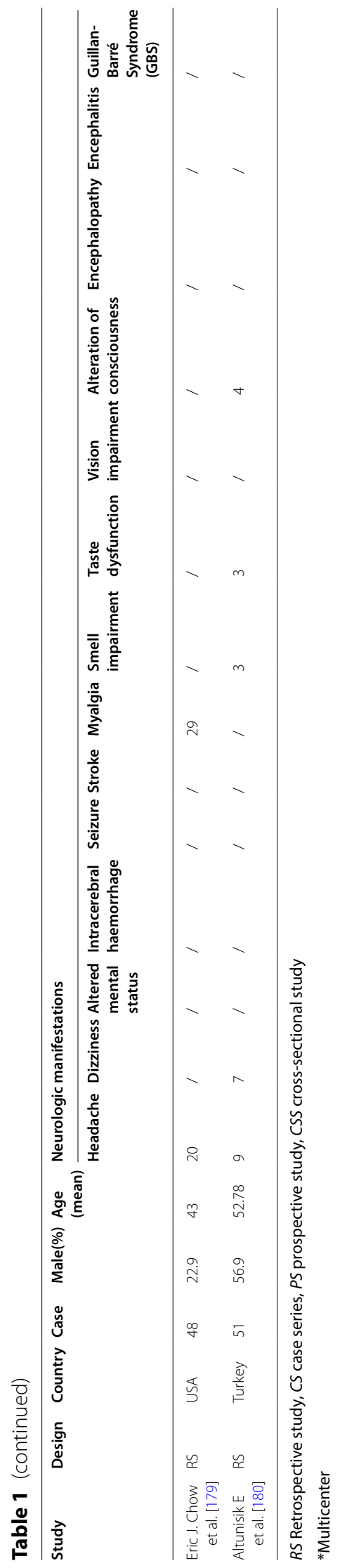




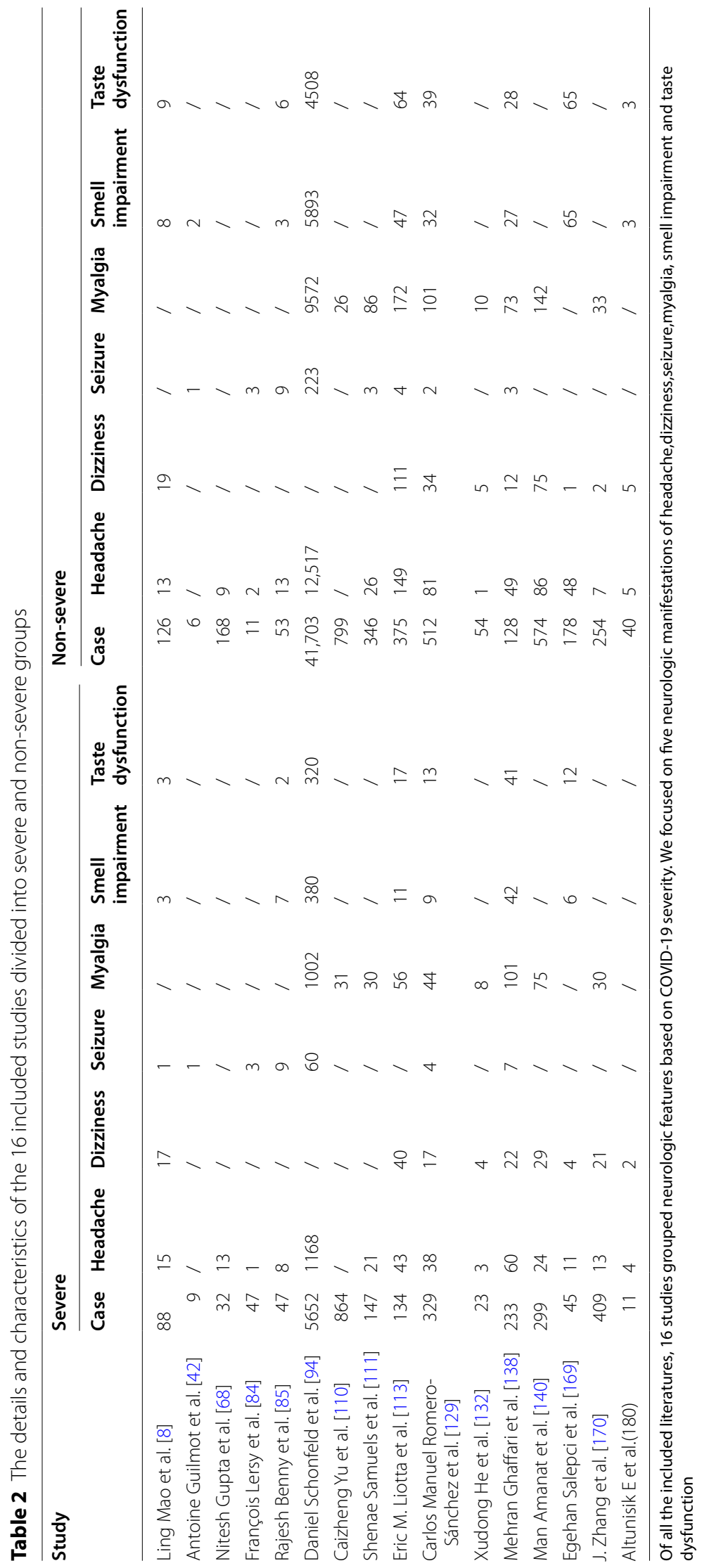


shows the details and characteristics of the 16 included studies divided into severe and non-severe groups.

Included studies had good methodological quality (Figs. 2, 3, 4, 5).

\section{Discussion}

According to our meta-analysis, the most common neurological manifestations of COVID-19 patients were myalgia (33\%), smell impairment (33\%), taste dysfunction (33\%) and altered mental status (32\%). It can be seen that both the central nervous system and peripheral nervous system will be involved after patients are infected with SARS-CoV-2. At the same time, considering the difference between symptoms and diseases, our study can conclude that the most common central nervous system symptoms are altered mental status (32\%), headache (29\%), alteration of consciousness (13\%), and dizziness (10\%). The most common central nervous system (CNS) disorders were encephalopathy (26\%), stroke $(12 \%)$, intracerebral haemorrhage $(5 \%)$, seizure $(4 \%)$, and encephalitis $(2 \%)$. The most common symptoms of peripheral nervous system (PNS) impairment were myalgia (33\%), smell impairment (33\%), taste dysfunction (33\%) and vision impairment (6\%). Guillan-Barre Syndrome (GBS) occurs in approximately $1 \%$ of peripheral nervous system disorder.

In addition, COVID-19 involvement in the peripheral nervous system includes other manifestations, such as cranial neuropathy and neuromuscular joint disease, etc. However, since only a few studies have reported such cases, and most of these studies were case reports, these less frequent COVID-19 peripheral nervous system manifestations were not included in this study. In the future, as more and more of these studies are reported, we can conduct further research.

Among 168 studies that were finally included in the meta-analysis, 123 studies discussed the incidence of headache, 106 studies discussed smell impairment, 86 studies discussed myalgia, and 80 studies discussed taste dysfunction. In our opinion, this also indirectly indicates that COVID-19 patients have symptoms of headache, smell impairment, myalgia and smell impairment earlier and have more cases, which is worthy of further study and discussion, to provide a diagnosis and treatment direction for early intervention in the future.

In 16 of the included studies, patients were divided into severe and non-severe groups for detailed analysis according to the severity of COVID-19 infection in patients. We found that the most studied neurological manifestations in this literature were headache, dizziness, seizure, myalgia, smell impairment and taste dysfunction. Our results showed that there was no significant difference in the incidence of headache between the two groups, both at 16\%; the incidence of dizziness and seizure in the severe COVID-19 group was higher than that in the non-severe group (12\% VS 9\%, 3\% VS 1\%, respectively). The incidence of myalgia, smell impairment and taste dysfunction in the severe COVID-19 group was lower than that in the non-severe group, which was $21 \%$ VS $24 \%$, $8 \%$ VS $13 \%$, 9\% VS 14\%, respectively. However, considering that the severity of COVID-19 disease is not classified the same according to different prevalence periods of COVID-19 and its prevalence in different countries, our statistical data may be biased to a certain extent, and the statistical results may lack a certain scientific nature. At the same time, there are still limited studies on various neurologic characteristics of COVID-19 under different severity, which deserves more research and exploration.

We also found that altered mental status, encephalopathy, and alteration of consciousness were reported separately, but they may be related to each other. Through reading different literature, we found that different researchers have different definitions of the above three aspects. Josef Anrather et al. [181] argue that altered mental status (e.g., confusion, disorientation, emotional restlessness and lethargy) can be collectively referred to as encephalopathy. Emad Nader Eskandar et al. [130] suggested that if there was evidence of cognitive impairment (e.g., confusion, disorientation, agitation or delirium) or impaired arousal (e.g., lethargy or dullness), the patient can be included in the altered mental status cohort. In another study, altered mental status was defined as including personality, behavior, cognition, and consciousness changes; encephalopathy, encephalitis; catatonia, mania, anxiety or depression, etc. [131]. We recognize that there may be overlapped parts among altered mental status, encephalopathy and alteration of consciousness, but they can all indicate that the central nervous system of patients is damaged, so their clinical reference value is not affected.

\section{Associations between neurologic manifestations and mechanisms of nervous system injury in patients with COVID-19}

ACE2 has been proved to be a functional receptor of SARS-CoV-2, which binds to the ACE2 receptor through its Spike (S) protein C-terminal domain (CTD) [182]. The expression profile of ACE2 is very extensive, and it is expressed in various regions of the human brain, such as the ventricle, motor cortex and posterior cingulum gyrus, middle temporal gyrus, substantial nigra, olfactory bulb, contralateral medulla oblongata, nucleus solitaries, vagus nerve, neurons, astrocytes, microglia and oligodendroglia, etc. [183, 184]. Therefore, the nervous system is at risk of SARS-COV-2 infection. The mechanism 

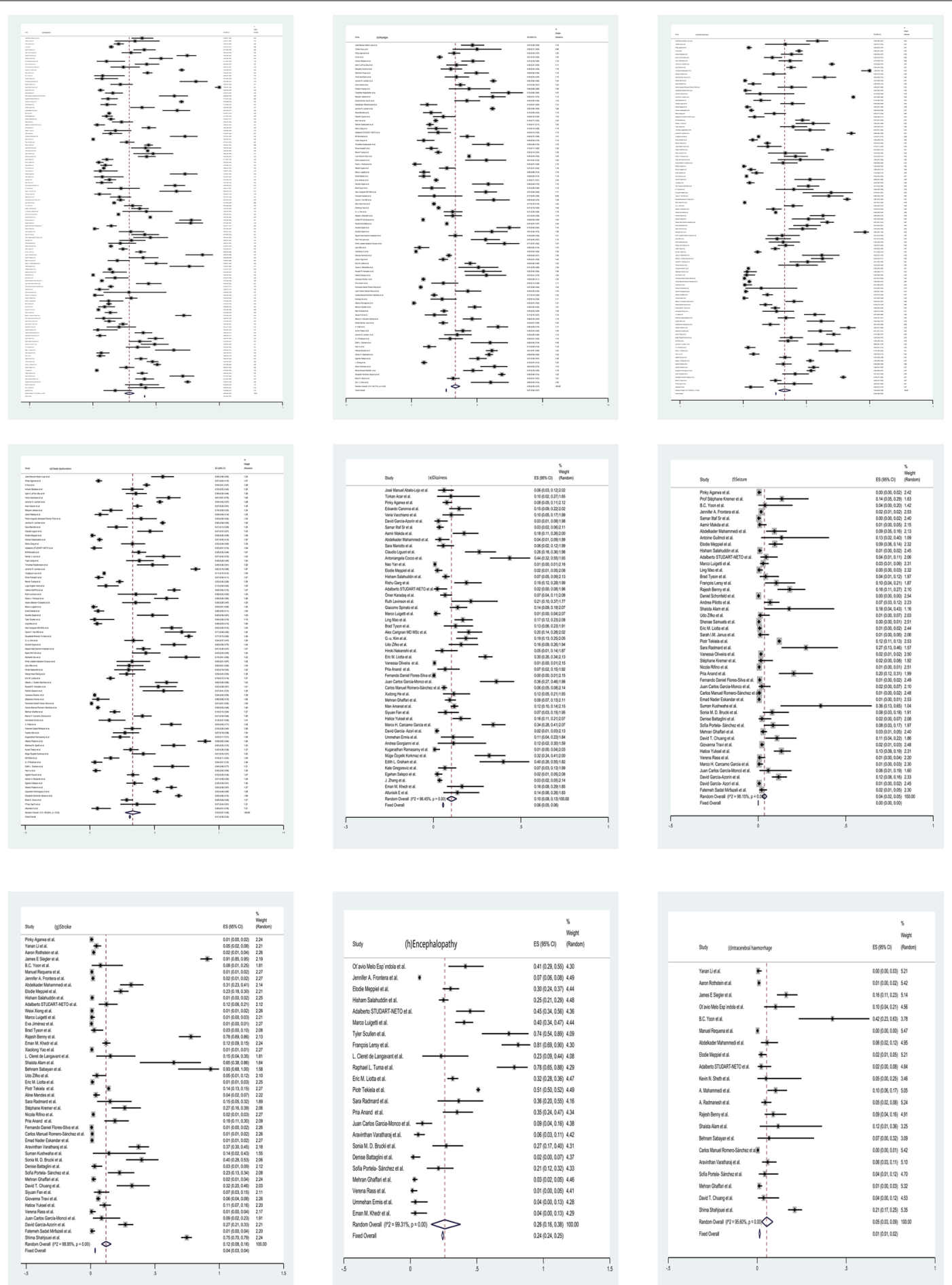

Fig. 2 Forest maps of neurological manifestations. a Headache, $\mathbf{b}$ myalgia, $\mathbf{c}$ smell impairment, $\mathbf{d}$ taste dysfunction, e dizziness, $\mathbf{f}$ seizure, $\mathbf{g}$ stroke, $\mathbf{h}$ encephalopathy, $\mathbf{i}$ intracerebral haemorrhage, $\mathbf{j}$ alteration of consciousness, $\mathbf{k}$ altered mental status, I vision impairment, $\mathbf{m}$ Guillan-Barré Syndrome (GBS) and $\mathbf{n}$ encephalitis. After the heterogeneity test, the results in figures $\mathbf{a}-\mathbf{n}$ all suggest that there was significant heterogeneity among the selected literature in this study 


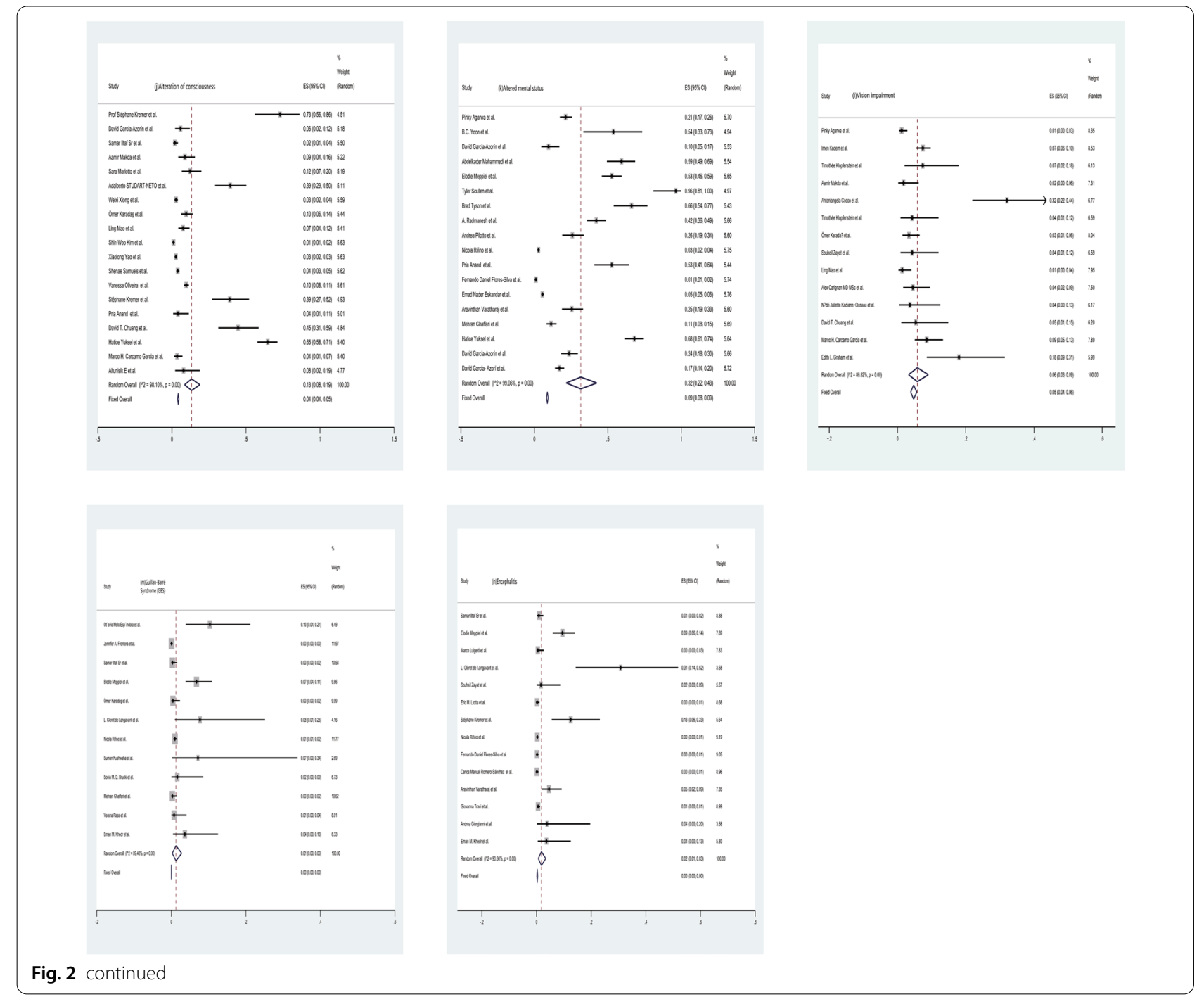

of nervous system injury in COVID-19 patients includes cross-neuronal hypothesis, homogenous transmission and $\mathrm{BBB}$ transmission, hypoxia, inflammatory response and hypercoagulability and immune mechanism as well. In the following sections, we will analyze and discuss the relationship between the neurological manifestations we have studied and the corresponding mechanisms of neurological damage.

\section{Altered mental status and alteration of consciousness}

The altered mental status and alteration of consciousness of COVID-19 patients may be a systemic consequence of the over-activation of the body's immune response or may be caused by the direct invasion of the nerves by SARS-COV2 $[185,186]$. Hypoxia, organ dysfunction, the need for large doses of sedatives, and prolonged isolation may also contribute to consciousness changes [181].

\section{Headache and dizziness}

Headaches and dizziness can be caused by a variety of causes. One reason may be the large and rapid increase of inflammatory cytokines, including IL-1, IL-6, and TNF $\alpha$, after infection. It can also cause pain if the virus invades the nervous system directly and damages the nerve. Hypoxia leads to the accumulation of acid in brain cells, swelling, and interstitial edema, resulting in cerebral vasodilation or cerebral blood flow obstruction, etc., which is also considered as one of the potential mechanisms of causing headache [185].

\section{Myalgia}

Because there are ACE2 receptors in skeletal muscle [187], direct cytotoxicity caused by the interaction between SARS-CoV-2 and ACE2 in skeletal muscle should be considered. Secondly, muscle injury 

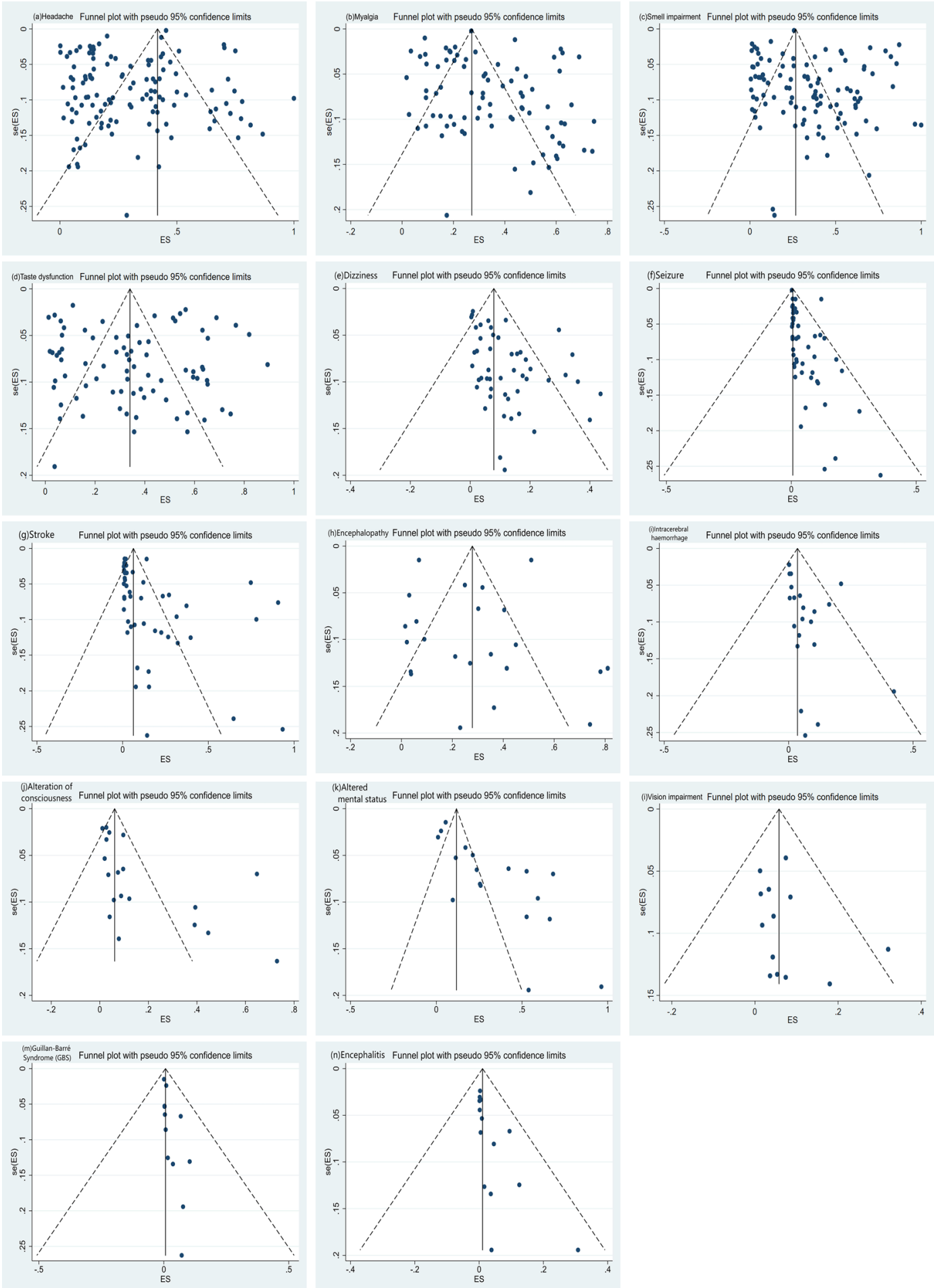

Fig. 3 Funnel plots. a Headache, $\mathbf{b}$ myalgia, c smell impairment, $\mathbf{d}$ taste dysfunction, e dizziness, $\mathbf{f}$ seizure, $\mathbf{g}$ stroke, $\mathbf{h}$ encephalopathy, i intracerebral haemorrhage, $\mathbf{j}$ alteration of consciousness, $\mathbf{k}$ altered mental status, I vision impairment, $\mathbf{m}$ Guillan-Barré Syndrome (GBS) and $\mathbf{n}$ encephalitis. After the bias test, the visual symmetry of the funnel plot and Egger's test showed that the publication of myalgia, taste dysfunction, encephalopathy and vision impairment was unbiased 


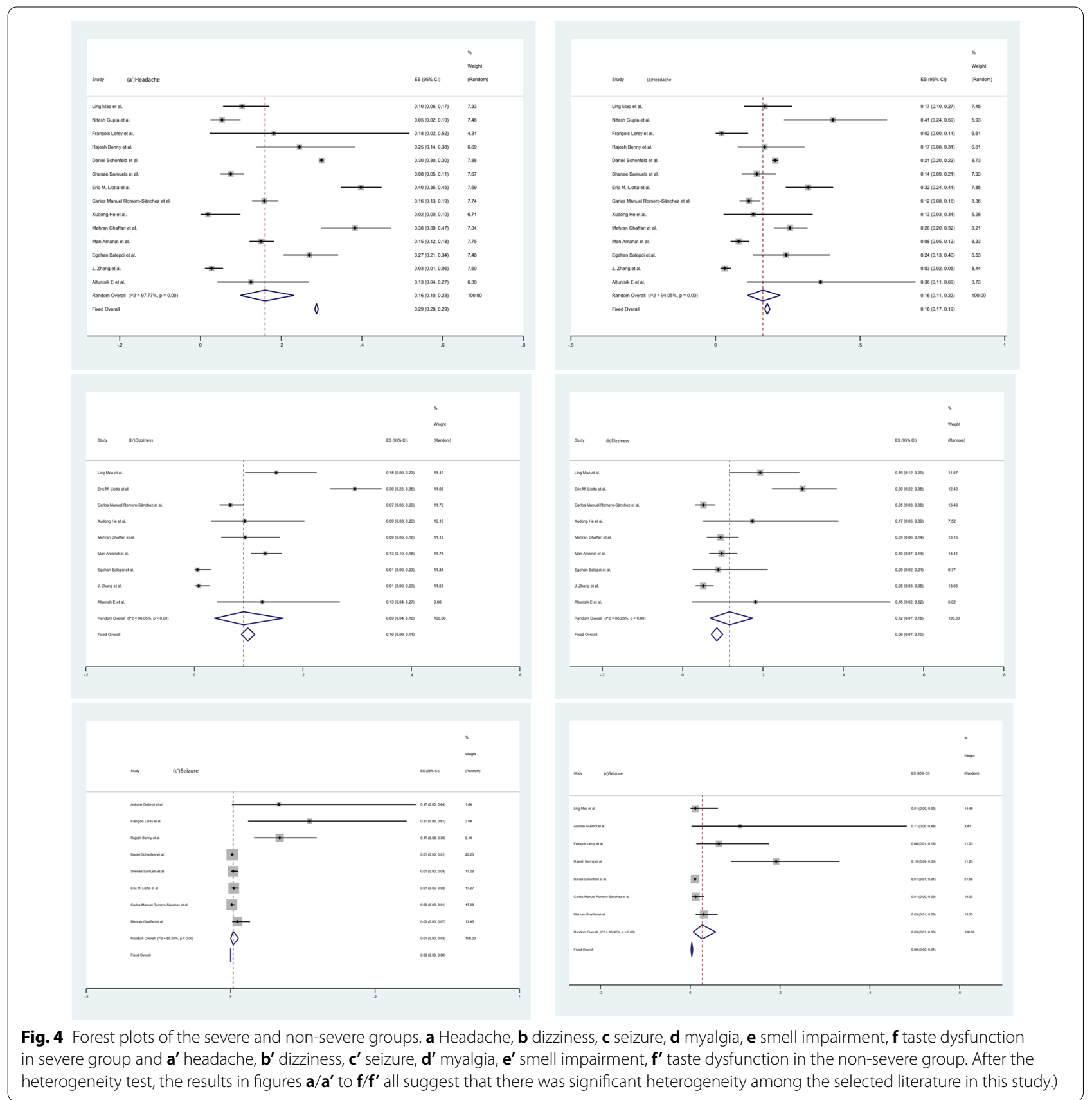

may be related to the harmful immune response mediated by infection and the increase of pro-inflammatory cytokines [8]. Elevated concentrations of $\mathrm{C}$-reactive protein and D-dimer in the blood may induce the expression of a strong immune response, leading to direct immune-mediated nerve and muscle injury [188]. At the same time, prolonged mechanical ventilation or the use of neuromuscular blockers in patients with severe COVID-19 infection is also closely related to the progression of critical myopathy [189].

\section{Smell impairment and taste dysfunction}

Studies have shown that the anosmia of most COVID19 patients has nothing to do with rhinorrhea or nasal obstruction, and may be related to the transmission of the virus through olfactory nerve epithelial cells and further invasion of the olfactory bulb and central nervous system $[43,190]$. It has been reported that higher levels of angiotensin can induce the apoptosis effect of neural stem cells [191], reducing the number of nerve cells migrating to the olfactory bulb, resulting in reduced replacement of 


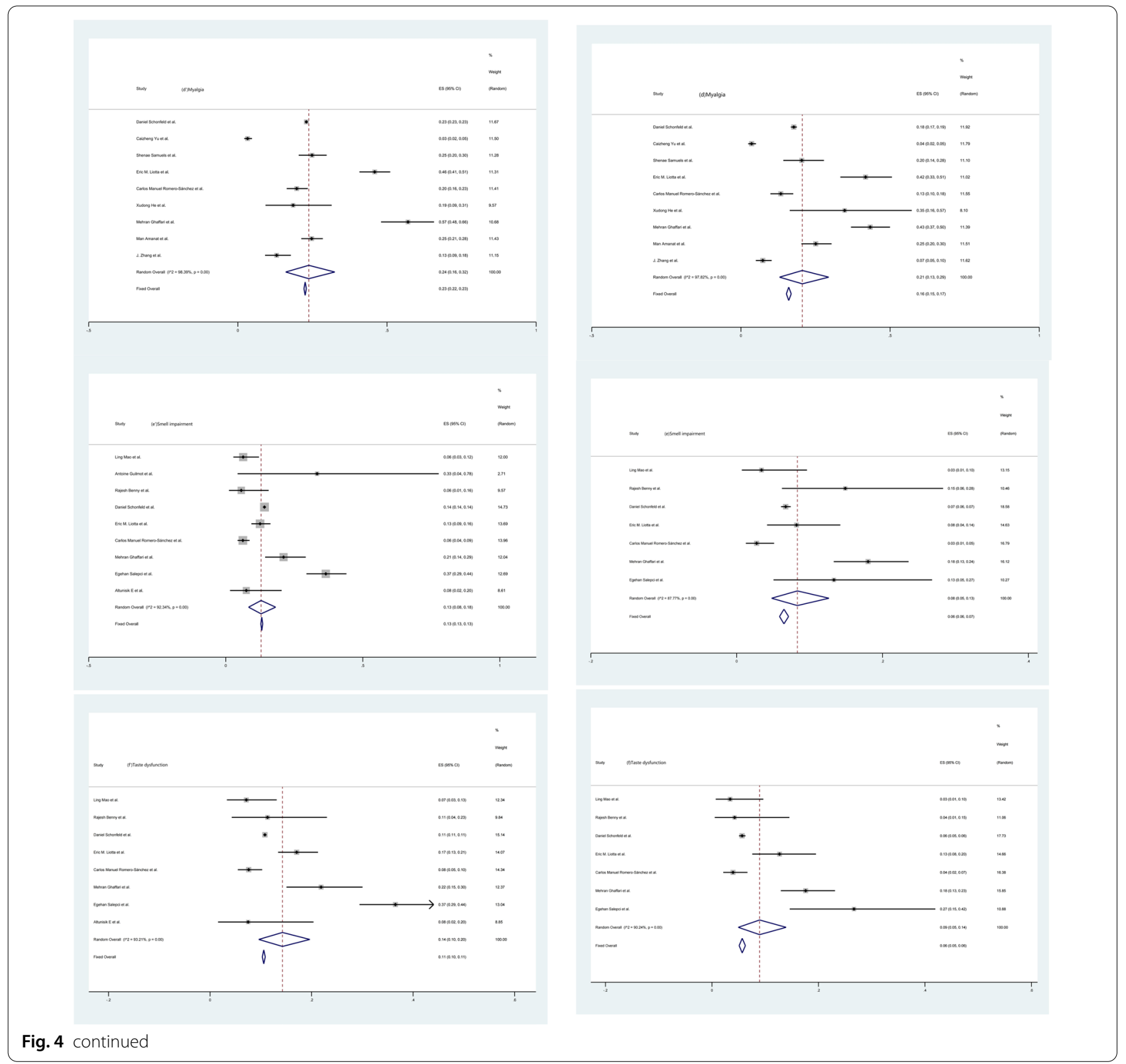

new neurons in the olfactory bulb, and interference with the smell. Animal experiments have shown that SARSCoV-2 may invade the brain retrograde along with taste and trigeminal nerve pathways in the early stage of infection, causing lesions such as taste disturbance [192].

\section{Encephalopathy and encephalitis}

Patients with COVID-19 may develop many types of encephalopathy. The combination of SARS-CoV-2 virus and ACE2 receptor increases peripheral vascular resistance, leading to a significant and rapid increase in blood pressure, triggering a cascade reaction that leads to the destruction of blood-brain barrier integrity, cerebral hyperperfusion, and cerebral edema, leading to the development of hypertensive encephalopathy [193, 194]. Hypoxia, insufficient energy supply, or overall insufficiency after severe brain injury can progress to hypoxicischemic encephalopathy. Steatosis, liver function damage, or cardiovascular dysfunction after COVID-19 infection may induce the occurrence of hepatic encephalopathy, which may be related to direct liver damage of SARS-CoV-2 or the side effects of some drugs $[195,196]$. In addition, recent studies have found an increased incidence of acute renal damage after SARS-CoV-2, and the 

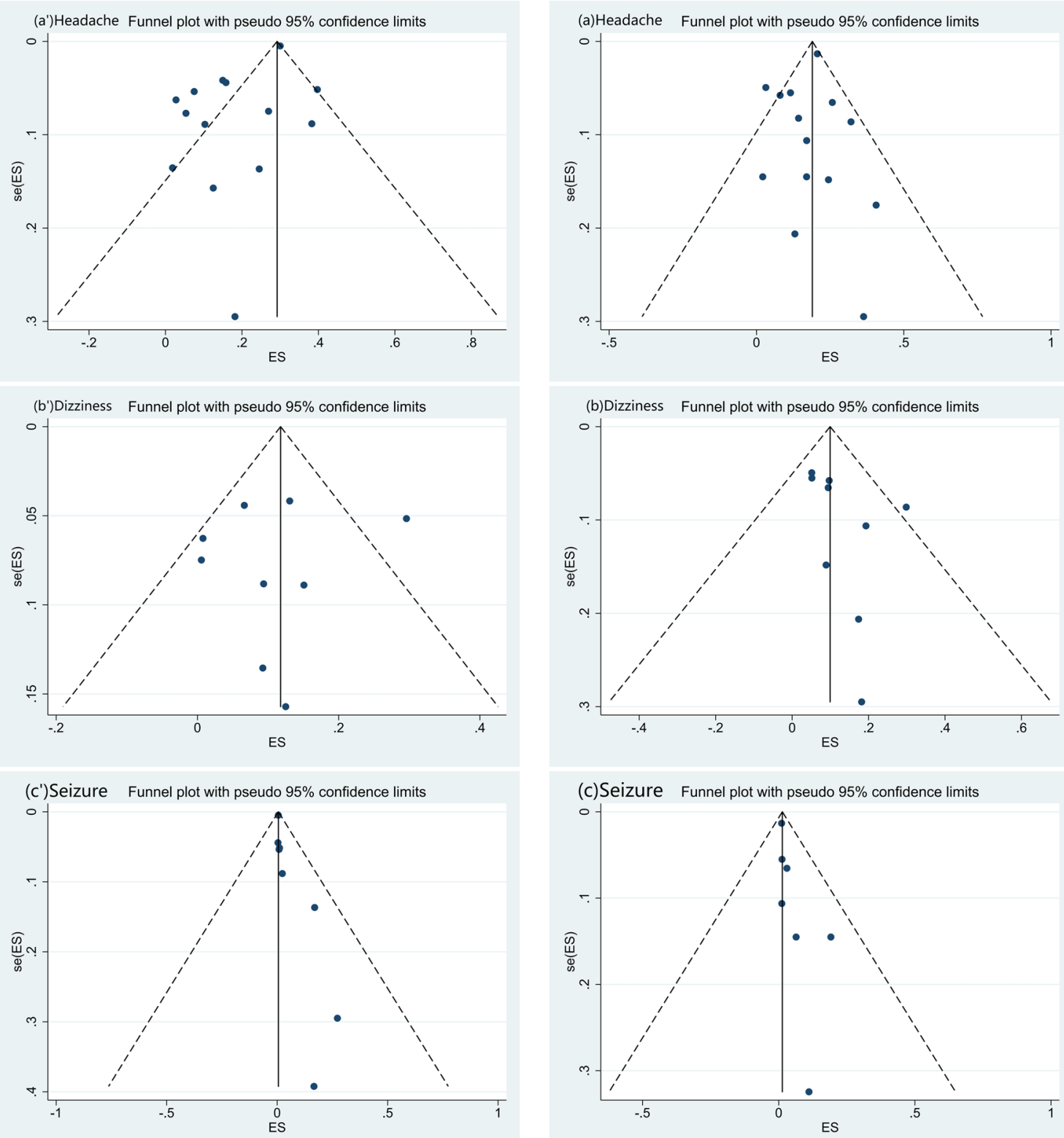

Fig. 5 Funnel plots for the severe and non-severe groups. a Headache, $\mathbf{b}$ dizziness, c seizure, $\mathbf{d}$ myalgia, e smell impairment, $\mathbf{f}$ taste dysfunction in severe group and $\mathbf{a}^{\prime}$ headache, $\mathbf{b}^{\prime}$ ' dizziness, $\mathbf{c}^{\prime}$ seizure, $\mathbf{d}^{\prime}$ myalgia, $\mathbf{e}^{\prime}$ smell impairment, $\mathbf{f}^{\prime}$ taste dysfunction in non-severe group. Funnel plot results and Egger's test showed that there was no publication bias in dizziness, seizure, myalgia, smell impairment, and taste dysfunction in both groups

pathophysiological mechanism remains unclear, which may also be caused by an inflammatory response, ACE/ ACE2 imbalance, or dysfunction of other organs (such as the heart). When patients have renal insufficiency, the body cannot completely discharge toxins and regulate the concentration of cytokines normally, and the brain homeostasis will be destroyed, leading to uremic encephalopathy [197]. When SARS-CoV-2 enters the human body through ACE2, the human body immediately generates an immune response. When the virus invades the brain, it will cause immune damage and lead to the attack of encephalitis [198]. Encephalitis may also be associated with blood-brain barrier disruption and cytokine surges [199].

\section{Stroke and intracerebral hemorrhage}

SARS-CoV-2 directly invades the nerve through ACE2 receptors and deregulation of blood pressure is the 

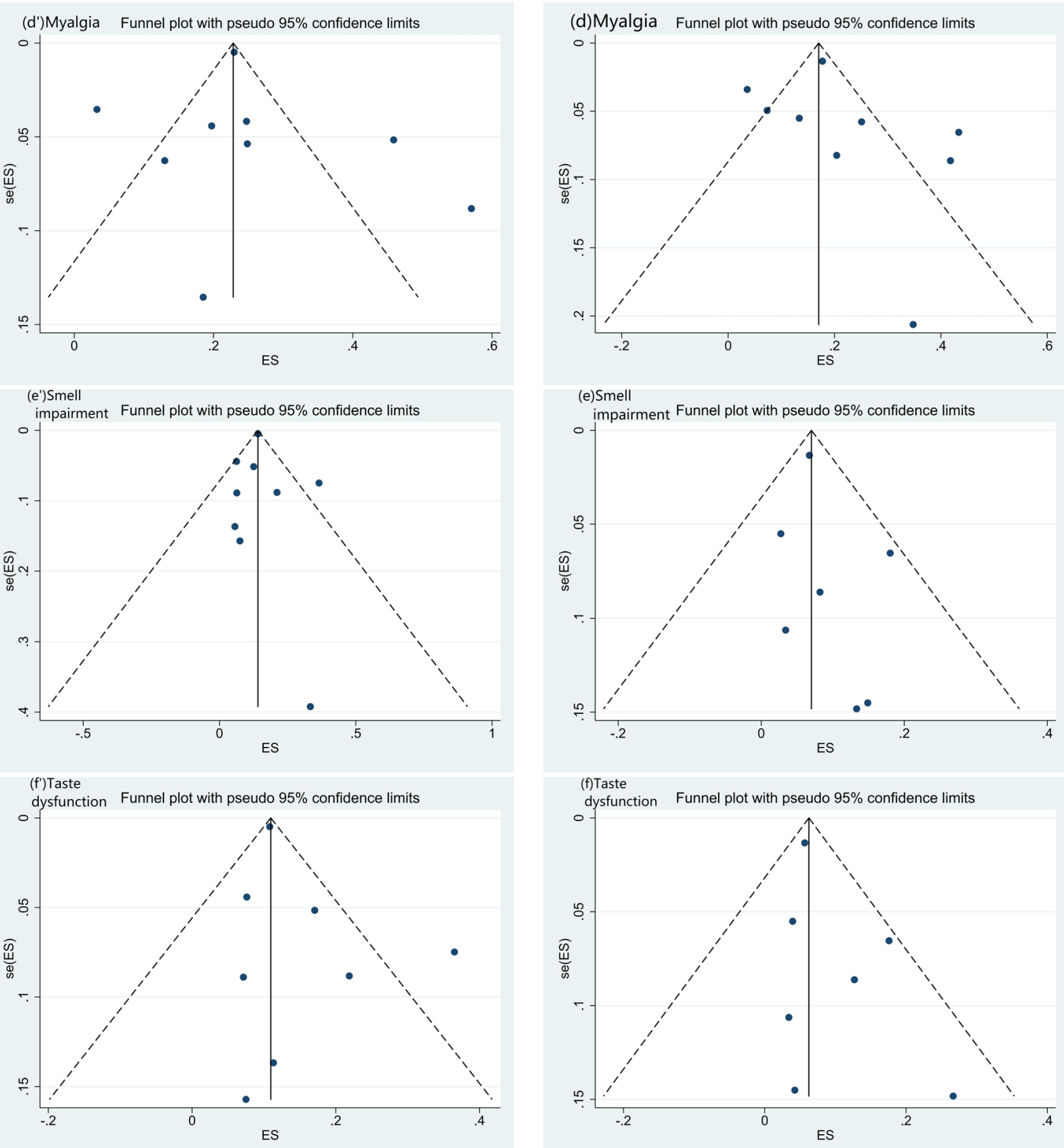

Fig. 5 continued

potential mechanism of COVID-19 stroke [200, 201]. Continuous hypoxia in COVID-19 patients will eventually lead to disorders in neurotransmitter metabolism and mitochondrial failure, causing irreversible nerve damage and increasing the risk of stroke [202]. Studies have shown that increased inflammatory markers such as IL-2, IL-6, macrophage inflammatory protein 1- $\alpha$ or coagulation dysfunction in patients with severe COVID19 may increase the likelihood of stroke compared with moderate patients [200]. After the SARS-CoV-2 virus binds to the ACE2 receptor, it can lead to increased blood pressure, which may lead to hypertensive crisis in severe cases and increase the risk of intracranial hemorrhage [188].

\section{Seizure}

The process of SARS-CoV-2 virus replication in host cells disrupts neuronal function and manifests as seizures, convulsions, and loss of consciousness [203]. The increase of pro-inflammatory mediators may contribute to epileptic seizures, which in turn enhance the production of cytokines such as IL-1B and TNF $\alpha$ [204]. After 
the destruction of the blood-brain barrier, inflammatory factors and viral particles flood into the central nervous system, leading to brain damage that can lead to epileptic seizures [188].

\section{Guillan-Barré Syndrome (GBS)}

Guillain-Barre syndrome (GBS) is an increasing occurrence in patients with COVID-19, a typical viral autoimmune nervous system disease caused by a strong immune response, which includes a range of polyneuropathy characterized by acute motor weakness, mild to moderate paresthesia, cranial nerve involvement, and muscle or nerve root pain [205]. At present, large sample studies on GBS are still lacking, and most researchers express their views in the form of case reports.

\section{Biomarkers reflecting nervous system damage in COVID-19 patients}

A prospective study showed that total Tau, GFAP, and NFL protein levels in cerebrospinal fluid were elevated in 63,37 , and $16 \%$ of patients, respectively, and NFL protein was associated with disease severity, duration of intensive care, and level of consciousness [206]. Multiple studies on COVID-19 patients with ischemic stroke have shown that the neutrophil-lymphocyte ratio (NLR) is increased in $90 \%$ of the patients [207], CRP is increased in over $90 \%$ of the patients [208], and serum ferritin is also increased [209], in which serum ferritin can also predict the degree of nerve injury in patients with acute ischemic stroke [210]. There was a significant correlation between the decrease of interleukin-6 level and the improvement of olfaction and taste function in COVID-19 patients [211]. Elevated serum nerve filament light chain (SNFL) levels in critically ill patients with COVID-19 are closely associated with poor prognosis [212].

\section{Examination methods reflecting nervous system damage in COVID-19 patients}

In our study, stroke incidence was $12 \%$, intracerebral hemorrhage 5\%, encephalopathy $26 \%$ and encephalitis 2\%. Studies have shown that patients with COVID-19 with acute neuroimaging abnormalities are more likely to have an ischemic stroke. Neuroimaging features of these patients are not invariable but are predominated by acute ischemic infarction, intracranial hemorrhage, and leukoencephalopathy [81]. COVID-19 is an independent risk factor for acute ischemic stroke and a valid indicator of poor prognosis. Meningitis and encephalitis are not very common [213, 214]. In one study, continuous EEG monitoring was performed in 11 of 16 patients with COVID-19, most of whom presented with nonspecific encephalopathy [215]. At the same time, some studies also found significant structural changes in the olfactory nerve, olfactory bulb, olfactory cortex and other olfactory pathways in MRI examination of COVID-19 patients, suggesting that SARS-CoV-2 may enter the central nervous system through the olfactory bulb mediated crossneuronal pathway [94, 95]. The relationship between COVID-19 imaging changes and neurological symptoms requires more research.

\section{Prognosis of nervous system injury in COVID-19 patients}

Nervous system damage is closely associated with the mortality of SARS-COV-2 infection, and whether the neurological symptoms are reversible is not yet clear. Patients with COVID-19 who require ICU admission for neurological problems or develop neurological dysfunction in the ICU have significantly increased mortality [216]. In one animal study, 4 out of 14 infected mice developed significant respiratory distress and neurological symptoms 2 days after infection, and only the mice showing neurological symptoms died, suggesting that neurological involvement may be a cause of death [217]. Some studies have confirmed that recovery from acute SARS-CoV-2 infection does not completely clear the virus, and has been found to have a higher potential risk for long-term residual neuropsychiatric and neuroscientist impairments, including depression, obsessive-compulsive disorder, psychosis, Parkinson's disease and Alzheimer's disease [218]. An experimental animal study has also shown that coronavirus can persist in the central nervous system of its host [219]. The study results of Helms et al. showed that $36 \%$ of severe COVID-19 survivors developed Dysfunction Syndrome [220], and some studies also reported that patients with severe dysfunction after the acute phase had significant recovery after active neurological rehabilitation [221]. In a prospective study, $68.33 \%$ of patients developed neurological symptoms during infection with SARS-CoV-2, and 50\% recovered 3 months after infection but still had neurological symptoms [213]. Imaging results of 60 patients after recovery of COVID-19 neurological symptoms suggest that the microstructure and functional brain integrity of the brain may be damaged during the rehabilitation phase, which may require long-term neurological and neuroimaging follow-up [214].

\section{Advantages and disadvantages of this study}

Our meta-analysis included 168 articles $(n=292,693)$ detailing the various neurologic symptoms common in COVID-19 patients and providing a comprehensive view of the neurologic symptoms of COVID-19. The results were comprehensive. We started the discussion of the clinical manifestations and analyzed the evidence, possible mechanism and prognosis of the nervous system injury caused by SARS-CoV-2. We also discussed the 
biomarkers and examination methods of nervous system injury caused by SARS-COV-2, providing some valuable suggestions for early identification, monitoring, screening, diagnosis and follow-up of nervous system injury and poor prognosis in patients with COVID-19 and potential targets for future clinical intervention strategies.

This study also has some limitations. Firstly, most of the included literature was retrospective studies, which may cause some potential bias. Secondly, this study failed to provide an analysis of the correlation between various neurological manifestations and disease severity and mortality. The question of which neurological manifestations are the most insidious and which are the most difficult to recover from is currently unanswered, and more findings will be needed in the future. Finally, the high degree of heterogeneity in our study may be due to differences in patient race selection, disease severity, comorbidities, only a few studies specifically assessed neurological symptoms, differences in the number of patients in different studies, or differences in publication bias and study methodology.

\section{Conclusion}

In conclusion, our study suggests that nervous system expression in COVID-19 is diverse and pervasive but easily underestimated. Therefore, the long-term pathophysiological results of SARS-COV-2 neuropathy should be of serious concern to us. At the same time, summarizing the entire symptom spectrum, biomarkers and examination methods of the disease is conducive to predicting the severity of neurological impairment and providing better suggestions for preventing misdiagnosis, early diagnosis, preventing disease transmission, early intervention treatment, evaluation of therapeutic effect and follow-up. In the future, more clinical and experimental studies should be carried out to provide strong evidence to support clinical practice, and further, explore the role of nervous system symptoms in the incidence of COVID-19 and its possible mechanism, to reduce mortality, reduce disease severity, control disease progression and prevent possible long-term nervous system complications.

\section{Acknowledgements}

Not applicable.

\section{Authors' contributions}

$\mathrm{ZH}$ and $\mathrm{HY}$ proposed the research idea. HY completed the data analysis and paper writing and was a major contributor in writing the manuscript.BX and ZT were responsible for literature retrieval and data extraction.HJ finished the quality evaluation. All authors read and approved the final manuscript.

\section{Funding:}

"Prevention, control, and treatment" three-ring linkage, major emergency rescue medical team construction research. Health soft science research key project of Anhui province in 2020.
Availability of data and materials

Not applicable.

\section{Declarations}

Ethics approval and consent to participate

Not applicable.

\section{Consent for publication}

Not applicable.

\section{Competing interests}

The authors declare that they have no competing interests.

Received: 6 March 2021 Accepted: 17 July 2021

Published online: 23 August 2021

References

1. Uhlén M, Fagerberg L, Hallström BM, et al. Proteomics. Tissue-based map of the human proteome. Science. 2015;347(6220):1260419. https://doi.org/10.1126/science.1260419.

2. Koralnik IJ, Tyler KL. COVID-19: a global threat to the nervous system. Ann Neurol. 2020;88(1):1-11. https://doi.org/10.1002/ana.25807.

3. Zhou Z, Kang H, Li S, Zhao X. Understanding the neurotropic characteristics of SARS-CoV-2: from neurological manifestations of COVID-19 to potential neurotropic mechanisms. J Neurol. 2020;267(8):2179-84. https://doi.org/10.1007/s00415-020-09929-7.

4. Das G, Mukherjee N, Ghosh S. Neurological insights of COVID-19 pandemic. ACS Chem Neurosci. 2020;11(9):1206-9. https://doi.org/10.1021/ acschemneuro.0c00201

5. Phan T. Genetic diversity and evolution of SARS-CoV-2. Infect Genet Evol. 2020;81: 104260. https://doi.org/10.1016/j.meegid.2020.104260.

6. Lai CC, Ko WC, Lee PI, Jean SS, Hsueh PR. Extra-respiratory manifestations of COVID-19. Int J Antimicrob Agents. 2020;56(2): 106024. https:// doi.org/10.1016/j.ijantimicag.2020.106024.

7. Khan S, Gomes J. Neuropathogenesis of SARS-CoV-2 infection. Elife. 2020;9:e59136. https://doi.org/10.7554/eLife.59136 (Published 2020 Jul 30).

8. Mao L, Jin H, Wang M, et al. Neurologic manifestations of hospitalized patients with coronavirus disease 2019 in Wuhan, China. JAMA Neurol. 2020;77(6):683-90. https://doi.org/10.1001/jamaneurol.2020.1127.

9. Studart-Neto A, Guedes BF, Tuma RLE, et al. Neurological consultations and diagnoses in a large, dedicated COVID-19 university hospital. Arq Neuropsiquiatr. 2020;78(8):494-500. https://doi.org/10.1590/0004282×20200089 (Published 2020 Aug 3).

10. Moriguchi T, Harii N, Goto J, et al. A first case of meningitis/encephalitis associated with SARS-Coronavirus-2. Int J Infect Dis. 2020;94:55-8. https://doi.org/10.1016/j.jijid.2020.03.062.

11. Khalili N, Haseli S, Bahrami-Motlagh H, et al. Neurologic involvement in COVID-19: radiologists' perspective. Acad Radiol. 2020;27(7):1051-3. https://doi.org/10.1016/j.acra.2020.04.035.

12. Wu P, Duan F, Luo C, et al. Characteristics of ocular findings of patients with coronavirus disease 2019 (COVID-19) in Hubei Province, China. JAMA Ophthalmol. 2020;138(5):575-8. https://doi.org/10.1001/jamao phthalmol.2020.1291.

13. Wu Z, McGoogan JM. Characteristics of and important lessons from the coronavirus disease 2019 (COVID-19) Outbreak in China: summary of a report of 72314 cases from the chinese center for disease control and prevention. JAMA. 2020;323(13):1239-42. https://doi.org/10.1001/jama. 2020.2648.

14. Ellul MA, Benjamin L, Singh B, et al. Neurological associations of COVID19. Lancet Neurol. 2020;19(9):767-83. https://doi.org/10.1016/S14744422(20)30221-0.

15. Abalo-Lojo JM, Pouso-Diz JM, Gonzalez F. Taste and smell dysfunction in COVID-19 patients. Ann Otol Rhinol Laryngol. 2020;129(10):1041-2. https://doi.org/10.1177/0003489420932617. 
16. Acar T, Acar BA, Aras YG, et al. Demographic characteristics and neurological comorbidity of patients with COVID-19. Rev Assoc Med Bras (1992). 2020;66(Suppl 2):82-5. https://doi.org/10.1590/1806-9282.66.S2. 82.

17. Agarwal P, Ray S, Madan A, Tyson B. Neurological manifestations in 404 COVID-19 patients in Washington State. J Neurol. 2020. https://doi.org/ 10.1007/s00415-020-10087-z (published online ahead of print, 2020 Aug 6).

18. Avcı H, Karabulut B, Farasoglu A, Boldaz E, Evman M. Relationship between anosmia and hospitalisation in patients with coronavirus disease 2019: an otolaryngological perspective. J Laryngol Otol. 2020;134(8):710-6. https://doi.org/10.1017/S0022215120001851.

19. Biadsee A, Biadsee A, Kassem F, Dagan O, Masarwa S, Ormianer Z. Olfactory and oral manifestations of COVID-19: sex-related symptomsa potential pathway to early diagnosis. Otolaryngol Head Neck Surg. 2020;163(4):722-8. https://doi.org/10.1177/0194599820934380.

20. Çalıca Utku A, Budak G, Karabay O, Güçlü E, Okan HD, Vatan A. Main symptoms in patients presenting in the COVID-19 period. Scott Med J. 2020;65(4):127-32. https://doi.org/10.1177/0036933020949253.

21. Caronna E, Ballvé A, Llauradó A, et al. Headache: a striking prodromal and persistent symptom, predictive of COVID-19 clinical evolution. Cephalalgia. 2020;40(13):1410-21. https://doi.org/10.1177/0333102420 965157.

22. Chary E, Carsuzaa F, Trijolet JP, et al. Prevalence and recovery from olfactory and gustatory dysfunctions in Covid-19 infection: a prospective multicenter study. Am J Rhinol Allergy. 2020;34(5):686-93. https://doi. org/10.1177/1945892420930954.

23. Li Y, Li M, Wang M, et al. Acute cerebrovascular disease following COVID19: a single center, retrospective, observational study. Stroke Vasc Neurol. 2020;5(3):279-84. https://doi.org/10.1136/svn-2020-000431.

24. Rothstein A, Oldridge O, Schwennesen H, Do D, Cucchiara BL. Acute cerebrovascular events in hospitalized COVID-19 patients. Stroke. 2020;51(9):e219-22. https://doi.org/10.1161/STROKEAHA.120.030995.

25 Siegler JE, Cardona P, Arenillas JF, et al. Cerebrovascular events and outcomes in hospitalized patients with COVID-19: The SVIN COVID-19 Multinational Registry. Int J Stroke. 2020. https://doi.org/10.1177/17474 93020959216 (published online ahead of print, 2020 Sep 30).

26. Kremer S, Lersy F, de Sèze J, et al. Brain MRI findings in severe COVID-19: a retrospective observational study. Radiology. 2020;297(2):E242-51. https://doi.org/10.1148/radiol.2020202222.

27. Vacchiano V, Riguzzi P, Volpi L, et al. Early neurological manifestations of hospitalized COVID-19 patients. Neurol Sci. 2020;41(8):2029-31. https:// doi.org/10.1007/s10072-020-04525-z.

28. Espíndola OM, Brandão CO, Gomes YCP, et al. Cerebrospinal fluid findings in neurological diseases associated with COVID-19 and insights into mechanisms of disease development. Int J Infect Dis. 2021;102:155-62. https://doi.org/10.1016/j.ijid.2020.10.044.

29. Lechien JR, Chiesa-Estomba CM, Place S, et al. Clinical and epidemiological characteristics of 1420 European patients with mild-to-moderate coronavirus disease 2019. J Intern Med. 2020;288(3):335-44. https://doi. org/10.1111/joim.13089.

30. Kacem I, Gharbi A, Harizi C, et al. Characteristics, onset, and evolution of neurological symptoms in patients with COVID-19. Neurol Sci. 2021;42(1):39-46. https://doi.org/10.1007/s10072-020-04866-9.

31. Yoon BC, Buch K, Lang M, et al. Clinical and neuroimaging correlation in patients with COVID-19. AJNR Am J Neuroradiol. 2020;41(10):1791-6. https://doi.org/10.3174/ajnr.A6717.

32. Huang C, Wang Y, Li X, et al. Clinical features of patients infected with 2019 novel coronavirus in Wuhan, China. Lancet. 2020;395(10223):497506. https://doi.org/10.1016/S0140-6736(20)30183-5 (published correction appears in Lancet. 2020 Jan 30;:).

33. Requena M, Olivé-Gadea M, Muchada M, et al. COVID-19 and stroke: incidence and etiological description in a high-volume center. J Stroke Cerebrovasc Dis. 2020;29(11): 105225. https://doi.org/10.1016/j.jstro kecerebrovasdis.2020.105225.

34. Frontera JA, Sabadia S, Lalchan R, et al. A Prospective study of neurologic disorders in hospitalized patients with COVID-19 in New York City. Neurology. 2021;96(4):e575-86. https://doi.org/10.1212/WNL.00000 00000010979
35. Klopfenstein T, Kadiane-Oussou NJ, Toko L, et al. Features of anosmia in COVID-19. Med Mal Infect. 2020;50(5):436-9. https://doi.org/10.1016/j. medmal.2020.04.006.

36. Jalessi M, Barati M, Rohani M, et al. Frequency and outcome of olfactory impairment and sinonasal involvement in hospitalized patients with COVID-19. Neurol Sci. 2020;41(9):2331-8. https://doi.org/10.1007/ s10072-020-04590-4.

37. García-Azorín D, Trigo J, Talavera B, et al. Frequency and type of red flags in patients with Covid-19 and headache: a series of 104 hospitalized patients. Headache. 2020;60(8):1664-72. https://doi.org/10.1111/head. 13927.

38 Iltaf S Sr, Fatima M, Salman S Sr, Salam JU, Abbas S. Frequency of neurological presentations of coronavirus disease in patients presenting to a tertiary care hospital during the 2019 coronavirus disease pandemic. Cureus. 2020;12(8):e9846. https://doi.org/10.7759/cureus.9846 (Published 2020 Aug 18).

39 Makda A, Kumar S, Kumar A, Kumar V, Rizwan A. The frequency of neurological symptoms in COVID-19 patients at a tertiary care hospital in Pakistan. Cureus. 2020;12(9):e10360. https://doi.org/10.7759/cureus. 10360 (Published 2020 Sep 10).

40. Rocha-Filho PAS, Magalhães JE. Headache associated with COVID-19: frequency, characteristics and association with anosmia and ageusia. Cephalalgia. 2020;40(13):1443-51. https://doi.org/10.1177/0333102420 966770.

41. Mahammedi A, Saba L, Vagal A, et al. Imaging of neurologic disease in hospitalized patients with COVID-19: an Italian multicenter retrospective observational study. Radiology. 2020;297(2):E270-3. https://doi.org/ 10.1148/radiol.2020201933.

42 Guilmot A, Maldonado Slootjes S, Sellimi A, et al. Immune-mediated neurological syndromes in SARS-CoV-2-infected patients. J Neurol. 2020. https://doi.org/10.1007/s00415-020-10108-x (published online ahead of print, $2020 \mathrm{Jul} \mathrm{30)}$.

43. Lechien JR, Chiesa-Estomba CM, Hans S, Barillari MR, Jouffe L, Saussez S. Loss of smell and taste in 2013 European patients with mild to moderate COVID-19. Ann Intern Med. 2020;173(8):672-5. https://doi.org/10. 7326/M20-2428.

44. Mariotto S, Savoldi A, Donadello K, et al. Nervous system: subclinical target of SARS-CoV-2 infection. J Neurol Neurosurg Psychiatry. 2020;91(9):1010-2. https://doi.org/10.1136/jnnp-2020-323881.

45. Liguori C, Pierantozzi M, Spanetta M, et al. Subjective neurological symptoms frequently occur in patients with SARS-CoV2 infection. Brain Behav Immun. 2020;88:11-6. https://doi.org/10.1016/j.bbi.2020.05.037.

46. Cocco A, Amami P, Desai A, Voza A, Ferreli F, Albanese A. Neurological features in SARS-CoV-2-infected patients with smell and taste disorder. J Neurol. 2020. https://doi.org/10.1007/s00415-020-10135-8 (published online ahead of print, 2020 Aug 7).

47. Yan N, Xu Z, Mei B, Gao Y, Lv D, Zhang J. Neurological implications of non-critically ill patients with coronavirus disease 2019 in a Fangcang Shelter Hospital in Wuhan, China. Front Neurol. 2020;11:895. https://doi. org/10.3389/fneur.2020.00895 (Published 2020 Aug 26).

48 Meppiel E, Peiffer-Smadja N, Maury A, et al. Neurologic manifestations associated with COVID-19: a multicentre registry. Clin Microbiol Infect. 2020. https://doi.org/10.1016/j.cmi.2020.11.005 (published online ahead of print, 2020 Nov 13).

49. Salahuddin H, Afreen E, Sheikh IS, et al. Neurological predictors of clinical outcomes in hospitalized patients with COVID-19. Front Neurol. 2020;11:585944. https://doi.org/10.3389/fneur.2020.585944 (Published 2020 Oct 30).

50. Garg R, Jain R, Sodani A, et al. Neurological symptoms as initial manifestation of Covid-19-an observational study. Ann Indian Acad Neurol. 2020;23(4):482-6. https://doi.org/10.4103/aian.AIAN_560_20.

51. Petrocelli M, Ruggiero F, Baietti AM, et al. Remote psychophysical evaluation of olfactory and gustatory functions in early-stage coronavirus disease 2019 patients: the Bologna experience of 300 cases. J Laryngol Otol. 2020;134(7):571-6. https://doi.org/10.1017/S0022215120001358.

52. Lee DJ, Lockwood J, Das P, Wang R, Grinspun E, Lee JM. Self-reported anosmia and dysgeusia as key symptoms of coronavirus disease 2019 CJEM. 2020;22(5):595-602. https://doi.org/10.1017/cem.2020.420.

53. Liang $Y, X u$ J, Chu $M$, et al. Neurosensory dysfunction: a diagnostic marker of early COVID-19. Int J Infect Dis. 2020;98:347-52. https://doi. org/10.1016/j.jijid.2020.06.086. 
54. Klopfenstein T, Zahra H, Kadiane-Oussou NJ, et al. New loss of smell and taste: uncommon symptoms in COVID-19 patients on Nord FrancheComte cluster. France Int J Infect Dis. 2020;100:117-22. https://doi.org/ 10.1016/j.ijid.2020.08.012.

55. Xiong W, Mu J, Guo J, et al. New onset neurologic events in people with COVID-1 9 in 3 regions in China. Neurology. 2020;95(11):e1479-87. https://doi.org/10.1212/WNL.0000000000010034.

56. Lechien JR, Chiesa-Estomba CM, De Siati DR, et al. Olfactory and gustatory dysfunctions as a clinical presentation of mild-to-moderate forms of the coronavirus disease (COVID-19): a multicenter European study. Eur Arch Otorhinolaryngol. 2020;277(8):2251-61. https://doi.org/10. 1007/s00405-020-05965-1.

57. Lee Y, Min P, Lee S, Kim SW. Prevalence and duration of acute loss of smell or taste in COVID-19 patients. J Korean Med Sci. 2020;35(18):e174. https://doi.org/10.3346/jkms.2020.35.e174 (Published 2020 May 11).

58. Karadaş Ö, Öztürk B, Sonkaya AR. A prospective clinical study of detailed neurological manifestations in patients with COVID-19. Neurol Sci. 2020;41(8):1991-5. https://doi.org/10.1007/s10072-020-04547-7.

59. Tudrej B, Sebo P, Lourdaux J, et al. Self-reported loss of smell and taste in SARS-CoV-2 patients: primary care data to guide future early detection strategies. J Gen Intern Med. 2020;35(8):2502-4. https://doi.org/10. 1007/s11606-020-05933-9.

60. Vaira LA, Deiana G, Fois AG, et al. Objective evaluation of anosmia and ageusia in COVID-19 patients: single-center experience on 72 cases. Head Neck. 2020;42(6):1252-8. https://doi.org/10.1002/hed.26204.

61. Dell'Era V, Farri F, Garzaro G, Gatto M, Aluffi Valletti P, Garzaro M. Smell and taste disorders during COVID-19 outbreak: cross-sectional study on 355 patients. Head Neck. 2020;42(7):1591-6. https://doi.org/10.1002/ hed.26288.

62. Díaz LA, García-Salum T, Fuentes-López E, Ferrés M, Medina RA, Riquelme A. Symptom profiles and risk factors for hospitalization in patients with SARS-CoV-2 and COVID-19: a large cohort from South America. Gastroenterology. 2020;159(3):1148-50. https://doi.org/10. 1053/j.gastro.2020.05.014

63. Levinson R, Elbaz M, Ben-Ami R, et al. Time course of anosmia and dysgeusia in patients with mild SARS-CoV-2 infection. Infect Dis (Lond). 2020;52(8):600-2. https://doi.org/10.1080/23744235.2020.1772992.

64. Fantozzi PJ, Pampena E, Di Vanna D, et al. Xerostomia, gustatory and olfactory dysfunctions in patients with COVID-19. Am J Otolaryngol. 2020;41(6): 102721. https://doi.org/10.1016/j.amjoto.2020.102721.

65. Chua AJ, Charn TC, Chan EC, Loh J. Acute olfactory loss is specific for COVID-19 at the emergency department. Ann Emerg Med. 2020;76(4):550-1. https://doi.org/10.1016/j.annemergmed.2020.05.015.

66. Beltrán-Corbellini Á, Chico-García JL, Martínez-Poles J, et al. Acute-onset smell and taste disorders in the context of COVID-19: a pilot multicentre polymerase chain reaction based case-control study. Eur J Neurol. 2020;27(9):1738-41. https://doi.org/10.1111/ene.14273.

67. Spinato G, Fabbris C, Polesel J, et al. Alterations in smell or taste in mildly symptomatic outpatients with SARS-CoV-2 infection. JAMA. 2020;323(20):2089-90. https://doi.org/10.1001/jama.2020.6771.

68. Gupta N, Ish P, Kumar R, et al. Evaluation of the clinical profile, laboratory parameters and outcome of two hundred COVID-19 patients from a tertiary centre in India. Monaldi Arch Chest Dis. 2020. https://doi.org/ 10.4081/monaldi.2020.1507 (Published 2020 Nov 9).

69. Luigetti M, lorio R, Bentivoglio AR, et al. Assessment of neurological manifestations in hospitalized patients with COVID-19. Eur J Neurol. 2020:27(11):2322-8. https://doi.org/10.1111/ene.14444.

70. Sakalli E, Temirbekov D, Bayri E, Alis EE, Erdurak SC, Bayraktaroglu M. Ear nose throat-related symptoms with a focus on loss of smell and/or taste in COVID-19 patients. Am J Otolaryngol. 2020;41(6): 102622. https://doi. org/10.1016/j.amjoto.2020.102622

71. Jiménez E, Fontán-Vela M, Valencia J, et al. Characteristics, complications and outcomes among 1549 patients hospitalised with COVID-19 in a secondary hospital in Madrid, Spain: a retrospective case series study. BMJ Open. 2020;10(11): e042398. https://doi.org/10.1136/bmjop en-2020-042398.

72. Huang Y, Tu M, Wang S, et al. Clinical characteristics of laboratory confirmed positive cases of SARS-CoV-2 infection in Wuhan, China: a retrospective single center analysis. Travel Med Infect Dis. 2020;36: 101606. https://doi.org/10.1016/j.tmaid.2020.101606.
73. Zayet S, Kadiane-Oussou NJ, Lepiller Q, et al. Clinical features of COVID19 and influenza: a comparative study on Nord Franche-Comte cluster. Microbes Infect. 2020;22(9):481-8. https://doi.org/10.1016/j.micinf.2020. 05.016 .

74. Scullen T, Keen J, Mathkour M, Dumont AS, Kahn L. Coronavirus 2019 (COVID-19)-associated encephalopathies and cerebrovascular disease: the New Orleans Experience. World Neurosurg. 2020;141:e437-46. https://doi.org/10.1016/j.wneu.2020.05.192.

75 Tyson B, Erdodi L, Ray S, Agarwal P. Altered mental status in 71 deaths due to COVID-19. Int J Neurosci. 2020. https://doi.org/10.1080/00207 454.2020.1825422 (published online ahead of print, 2020 Oct 1).

76. Carignan A, Valiquette L, Grenier C, et al. Anosmia and dysgeusia associated with SARS-CoV-2 infection: an age-matched case-control study. CMAJ. 2020;192(26):E702-7. https://doi.org/10.1503/cmaj.200869.

77. Hornuss D, Lange B, Schröter N, Rieg S, Kern WV, Wagner D. Anosmia in COVID-19 patients. Clin Microbiol Infect. 2020;26(10):1426-7. https:// doi.org/10.1016/j.cmi.2020.05.017.

78. Heidari F, Karimi E, Firouzifar M, et al. Anosmia as a prominent symptom of COVID-19 infection. Rhinology. 2020;58(3):302-3. https://doi.org/10. 4193/Rhin20.140.

79. Sheth KN, Mazurek MH, Yuen MM, et al. Assessment of brain injury using portable, low-field magnetic resonance imaging at the bedside of critically ill patients. JAMA Neurol. 2020. https://doi.org/10.1001/ jamaneurol.2020.3263 (published online ahead of print, 2020 Sep 8)

80. Yan CH, Faraji F, Prajapati DP, Boone CE, DeConde AS. Association of chemosensory dysfunction and COVID-19 in patients presenting with influenza-like symptoms. Int Forum Allergy Rhinol. 2020;10(7):806-13. https://doi.org/10.1002/alr.22579.

81 Mahammedi A, Ramos A, Bargalló N, et al. Brain and lung imaging correlation in patients with COVID-19: could the severity of lung disease reflect the prevalence of acute abnormalities on neuroimaging? A global multicenter observational study. AJNR Am J Neuroradiol. 2021. https://doi.org/10.3174/ajnr.A7072 (published online ahead of print, 2021 Mar 11)

82. Radmanesh A, Raz E, Zan E, Derman A, Kaminetzky M. Brain imaging use and findings in COVID-19: a single academic center experience in the epicenter of disease in the United States. AJNR Am J Neuroradiol. 2020:41(7):1179-83. https://doi.org/10.3174/ajnr.A6610.

83. Lin E, Lantos JE, Strauss SB, et al. Brain imaging of patients with COVID-19: findings at an academic institution during the height of the outbreak in New York City. AJNR Am J Neuroradiol. 2020;41(11):2001-8. https://doi.org/10.3174/ajnr.A6793.

84. Lersy F, Benotmane I, Helms J, et al. Cerebrospinal fluid features in patients with coronavirus disease 2019 and neurological manifestations: correlation with brain magnetic resonance imaging findings in 58 patients. J Infect Dis. 2021;223(4):600-9. https://doi.org/10.1093/infdis/ jiaa745.

85. Benny R, Singh RK, Venkitachalam A, et al. Characteristics and outcomes of 100 consecutive patients with acute stroke and COVID-19. J Neurol Sci. 2021;423: 117348. https://doi.org/10.1016/j.jns.2021.117348.

86. Brandão Neto D, Fornazieri MA, Dib C, et al. Chemosensory dysfunction in COVID-19: prevalences, recovery rates, and clinical associations on a large Brazilian sample. Otolaryngol Head Neck Surg. 2021;164(3):512-8. https://doi.org/10.1177/0194599820954825.

87 Khedr EM, Soliman RK, Abo-Elfetof N, et al. Clinical and radiological characteristics of acute cerebrovascular diseases among egyptian patients with COVID-19 in upper Egypt. Front Neurol. 2021;12: 635856. https://doi.org/10.3389/fneur.2021.635856 (Published 2021 Mar 22).

88. Kim SW, Kim SM, Kim YK, et al. Clinical characteristics and outcomes of covid-19 cohort patients in Daegu Metropolitan City outbreak in 2020. J Korean Med Sci. 2021;36(1): e12. https://doi.org/10.3346/jkms. 2021.36.e12.

89. Yao X, Liu S, Wang J, et al. The clinical characteristics and prognosis of COVID-19 patients with cerebral stroke: a retrospective study of 113 cases from one single-centre. Eur J Neurosci. 2021;53(4):1350-61. https://doi.org/10.1111/ejn.15007.

90. Kim GU, Kim MJ, Ra SH, et al. Clinical characteristics of asymptomatic and symptomatic patients with mild COVID-19. Clin Microbiol Infect. 2020;26(7):948.e1-948.e3. https://doi.org/10.1016/j.cmi.2020.04.040. 
91. Brendish NJ, Poole S, Naidu WV, et al. Clinical characteristics, symptoms and outcomes of 1054 adults presenting to hospital with suspected COVID-19: a comparison of patients with and without SARS-CoV-2 infection. J Infect. 2020;81(6):937-43. https://doi.org/10. 1016/j.jinf.2020.09.033.

92 CleretdeLangavant L, Petit A, Nguyen QTR, et al. Clinical description of the broad range of neurological presentations of COVID-19: a retrospective case series. Rev Neurol (Paris). 2021;177(3):275-82. https:// doi.org/10.1016/j.neurol.2021.01.004.

93. de Souza CD, de Arruda Magalhães AJ, Lima AJ, et al. Clinical manifestations and factors associated with mortality from COVID-19 in older adults: retrospective population-based study with 9807 older Brazilian COVID-19 patients. Geriatr Gerontol Int. 2020;20(12):1177-81. https://doi.org/10.1111/ggi.14061.

94 Schönfeld D, Arias S, Bossio JC, Fernández H, Gozal D, Pérez-Chada D. Clinical presentation and outcomes of the first patients with COVID19 in Argentina: results of 207079 cases from a national database. PLoS ONE. 2021;16(2): e0246793. https://doi.org/10.1371/journal. pone.0246793 (Published 2021 Feb 11).

95. Tuma RL, Guedes BF, Carra R, et al. Clinical, cerebrospinal fluid, and neuroimaging findings in COVID-19 encephalopathy: a case series. Neurol Sci. 2021;42(2):479-89. https://doi.org/10.1007/ s10072-020-04946-W.

96. Zayet $\mathrm{S}$, Klopfenstein T, Mercier J, et al. Contribution of anosmia and dysgeusia for diagnostic of COVID-19 in outpatients. Infection. 2021;49(2):361-5. https://doi.org/10.1007/s15010-020-01442-3.

97. Zayet S, Kadiane-Oussou NJ, Royer PY, Toko L, Gendrin V, Klopfenstein T. Coronavirus disease 2019: new things to know! J Med Virol. 2020;92(10):1767-8. https://doi.org/10.1002/jmv.25874.

98. Samimi Ardestani SH, Mohammadi Ardehali M, Rabbani Anari M, et al. The coronavirus disease 2019: the prevalence, prognosis, and recovery from olfactory dysfunction (OD). Acta Otolaryngol. 2021;141(2):171-80. https://doi.org/10.1080/00016489.2020.1836397.

99. Pilotto A, Benussi A, Libri I, et al. COVID-19 impact on consecutive neurological patients admitted to the emergency department. J Neurol Neurosurg Psychiatry. 2021;92(2):218-20. https://doi.org/10. 1136/jnnp-2020-323929.

100. Schneider A, Kirsten H, Lordick F, Lordick F, Lübbert C, von Braun A. Covid-19 in outpatients-Is fever a useful indicator for SARS-CoV-2 infection? PLoS ONE. 2021;16(2): e0246312. https://doi.org/10.1371/ journal.pone.0246312 (published correction appears in PLoS One. 2021 May 6;16(5):e0251623).

101. Alam S, Dharia RN, Miller E, Rincon F, Tzeng DL, Bell RD. Coronavirus positive patients presenting with stroke-like symptoms. J Stroke Cerebrovasc Dis. 2021;30(4): 105588. https://doi.org/10.1016/j.jstro kecerebrovasdis.2020.105588.

102. Sabayan B, Moghadami M, Assarzadegan F, et al. COVID-19 respiratory illness and subsequent cerebrovascular events, the initial iranian experience. J Stroke Cerebrovasc Dis. 2021;30(1): 105454. https://doi. org/10.1016/j.jstrokecerebrovasdis.2020.105454.

103. Cho RHW, To ZWH, Yeung ZWC, et al. COVID-19 viral load in the severity of and recovery from olfactory and gustatory dysfunction. Laryngoscope. 2020;130(11):2680-5. https://doi.org/10.1002/lary. 29056.

104 Lan FY, Filler R, Mathew S, et al. COVID-19 symptoms predictive of healthcare workers'SARS-CoV-2 PCR results. PLoS ONE. 2020;15(6): e0235460. https://doi.org/10.1371/journal.pone.0235460 (Published 2020 Jun 26)

105. Dev N, Sankar J, Gupta N, et al. COVID-19 with and without anosmia or dysgeusia: a case-control study. J Med Virol. 2021;93(4):2499-504. https://doi.org/10.1002/jmv.26784.

106. Kadiane-Oussou NJ, Klopfenstein T, Royer PY, Toko L, Gendrin V, Zayet S. COVID-19: comparative clinical features and outcome in 114 patients with or without pneumonia (Nord Franche-Comte Hospital, France). Microbes Infect. 2020;22(10):622-5. https://doi.org/10.1016/j.micinf. 2020.10.002.

107. Zifko U, Schmiedlechner T, Saelens J, et al. Covid-19: Involvement of the nervous system. Identifying neurological predictors defining the course of the disease. J Neurol Sci. 2021;425: 117438. https://doi.org/10.1016/j. jns.2021.117438.
108. Nakanishi H, Suzuki M, Maeda H, et al. Differential diagnosis of COVID19: importance of measuring blood lymphocytes, serum electrolytes, and olfactory and taste functions. Tohoku J Exp Med. 2020;252(2):10919. https://doi.org/10.1620/tjem.252.109.

109. Sheng WH, Liu WD, Wang JT, Chang SY, Chang SC. Dysosmia and dysgeusia in patients with COVID-19 in northern Taiwan. J Formos Med Assoc. 2021;120(1 Pt 2):311-7. https://doi.org/10.1016/j.jfma.2020.10. 003.

110. Yu C, Lei Q, Li W, Wang X, Li W, Liu W. Epidemiological and clinical characteristics of 1663 hospitalized patients infected with COVID-19 in Wuhan, China: a single-center experience. J Infect Public Health. 2020;13(9):1202-9. https://doi.org/10.1016/j.jiph.2020.07.002.

111. Samuels S, Niu J, Sareli C, Eckardt P. The epidemiology and predictors of outcomes among confirmed COVID-19 cases in a large community healthcare system in South Florida. J Community Health. 2021. https:// doi.org/10.1007/s10900-020-00957-y (published online ahead of print, 2021 Jan 7).

112. Trigo J, García-Azorín D, Planchuelo-Gómez Á, et al. Factors associated with the presence of headache in hospitalized COVID-19 patients and impact on prognosis: a retrospective cohort study. J Headache Pain. 2020;21 (1):94. https://doi.org/10.1186/s10194-020-01165-8 (Published 2020 Jul 29).

113. Liotta EM, Batra A, Clark JR, et al. Frequent neurologic manifestations and encephalopathy-associated morbidity in Covid-19 patients. Ann Clin Transl Neurol. 2020;7(11):2221-30. https://doi.org/10.1002/acn3. 51210.

114 Membrilla JA, de Lorenzo I, Sastre M, Díaz de Terán J. Headache as a cardinal symptom of coronavirus disease 2019: a cross-sectional study. Headache. 2020;60(10):2176-91. https://doi.org/10.1111/head.13967.

115. Coppola A, Tonini MC, Baratelli E, et al. Headache in a group of SARSCOVID-19 patients: an observational prospectical study. Neurol Sci. 2020;41 (Suppl 2):503-4. https://doi.org/10.1007/s10072-020-04676-z.

116. Janus SIM, Schepel AAM, Zuidema SU, de Haas EC. How typical is the spectrum of COVID-19 in nursing home residents? J Am Med Dir Assoc. 2021;22(3):511-513.e3. https://doi.org/10.1016/j.jamda.2020.12.028.

117. Tekiela P, Majersik JJ. The impact of COVID-19 on developing neurologic disorders. Neurology. 2021;96(4):e647-9. https://doi.org/10.1212/WNL. 0000000000011348.

118. Guillén Martínez A, Andreu Gálvez M, Rodríguez Sanz S, Hernández Ruiz P, García Morillas A, Esteban ST. Incidence of smell and taste disorders and associated factors in patients with mild to moderate COVID-19. Otolaryngol Pol. 2020;75(2):1-5. https://doi.org/10.5604/01.3001.0014. 3451.

119. Mendes A, Herrmann FR, Genton L, et al. Incidence, characteristics and clinical relevance of acute stroke in old patients hospitalized with COVID-19. BMC Geriatr. 2021;21(1):52. https://doi.org/10.1186/s12877021-02006-2 (Published 2021 Jan 14).

120 Radmard S, Epstein SE, Roeder HJ, et al. Inpatient neurology consultations during the onset of the SARS-CoV-2 New York City pandemic: a single center case series. Front Neurol. 2020;11:805. https://doi.org/10. 3389/fneur.2020.00805.

121. Kempker RR, Kempker JA, Peters M, et al. Loss of smell and taste among healthcare personnel screened for coronavirus 2019. Clin Infect Dis. 2021;72(7):1244-6. https://doi.org/10.1093/cid/ciaa877.

122. Dawson P, Rabold EM, Laws RL, et al. Loss of taste and smell as distinguishing symptoms of coronavirus disease 2019. Clin Infect Dis. 2021;72(4):682-5. https://doi.org/10.1093/cid/ciaa799.

123. Oliveira V, Seabra M, Rodrigues R, et al. Neuro-COVID frequency and short-term outcome in the Northern Portuguese population. Eur J Neurol. 2021. https://doi.org/10.1111/ene.14874 (published online ahead of print, 2021 Apr 21).

124. Kremer S, Lersy F, Anheim M, et al. Neurologic and neuroimaging findings in patients with COVID-19: a retrospective multicenter study. Neurology. 2020;95(13):e1868-82. https://doi.org/10.1212/WNL.00000 00000010112.

125. Rifino N, Censori B, Agazzi E, et al. Neurologic manifestations in 1760 COVID-19 patients admitted to Papa Giovanni XXIII Hospital, Bergamo, Italy. J Neurol. 2020. https://doi.org/10.1007/s00415-020-10251-5 (published online ahead of print, 2020 Oct 7).

126. Anand P, Zhou L, Bhadelia N, Hamer DH, Greer DM, Cervantes-Arslanian AM. Neurologic findings among inpatients with COVID-19 at a 
safety-net US Hospital. Neurol Clin Pract. 2021;11(2):e83-91. https://doi. org/10.1212/CPJ.0000000000001031.

127. Flores-Silva FD, García-Grimshaw M, Valdés-Ferrer SI, et al. Neurologic manifestations in hospitalized patients with COVID-19 in Mexico City. PLoS ONE. 2021;16(4): e0247433. https://doi.org/10.1371/journal.pone. 0247433 (Published 2021 Apr 8).

128. García-Moncó JC, Cabrera Muras A, Erburu Iriarte M, et al. Neurologic manifestations in a prospective unselected series of hospitalized patients with COVID-19. Neurol Clin Pract. 2021;11(2):e64-72. https:// doi.org/10.1212/CPJ.00000000000000913.

129. Romero-Sánchez CM, Díaz-Maroto I, Fernández-Díaz E, et al. Neurologic manifestations in hospitalized patients with COVID-19: the ALBACOVID registry. Neurology. 2020;95(8):e1060-70. https://doi.org/10.1212/WNL. 0000000000009937.

130. Eskandar EN, Altschul DJ, de la Garza Ramos R, et al. Neurologic syndromes predict higher in-hospital mortality in COVID-19. Neurology. 2021;96(11):e1527-38. https://doi.org/10.1212/WNL.0000000000 011356 (published correction appears in Neurology. 2021 Mar 16;96(11):551).

131 Varatharaj A, Thomas N, Ellul MA, et al. Neurological and neuropsychiatric complications of COVID-19 in 153 patients: a UK-wide surveillance study. Lancet Psychiatry. 2020;7(10):875-82. https://doi.org/10.1016/ S2215-0366(20)30287-X (published correction appears in Lancet Psychiatry. 2020 Jul 14;:).

132. He X, Zhang D, Zhang L, et al. Neurological and psychiatric presentations associated with COVID-19. Eur Arch Psychiatry Clin Neurosci. 2021 https://doi.org/10.1007/s00406-021-01244-0 (published online ahead of print, 2021 Mar 12).

133 Kushwaha S, Seth V, Bapat P, et al. Neurological associations of COVID19-do we know enough: a tertiary care hospital based study. Front Neurol. 2020;11: 588879. https://doi.org/10.3389/fneur.2020.588879 (Published 2020 Nov 24)

134. Romagnolo A, Balestrino R, Imbalzano G, et al. Neurological comorbidity and severity of COVID-19. J Neurol. 2021;268(3):762-9. https://doi. org/10.1007/s00415-020-10123-y.

135. Brucki SMD, Corazza LA, de Queiroz AP, et al. Neurological complications in COVID-19 patients from Latin America. Brain. 2021;144(3): e29. https://doi.org/10.1093/brain/awaa440.

136 Battaglini D, Santori G, Chandraptham K, et al. Neurological complications and noninvasive multimodal neuromonitoring in critically ill mechanically ventilated COVID-19 patients. Front Neurol. 2020;1 1: 602114. https://doi.org/10.3389/fneur.2020.602114

137 Portela-Sánchez S, Sánchez-Soblechero A, Melgarejo Otalora PJ, et al. Neurological complications of COVID-19 in hospitalized patients: the registry of a neurology department in the first wave of the pandemic. Eur J Neurol. 2021. https://doi.org/10.1111/ene.14748 (published online ahead of print, 2021 Jan 21).

138. Ghaffari M, Ansari H, Beladimoghadam N, et al. Neurological features and outcome in COVID-19: dementia can predict severe disease. J Neurovirol. 2021;27(1):86-93. https://doi.org/10.1007/s13365-020-00918-0.

139. Chuang DT, Aydemir S, Magda P, Thomas C, Zarnegar R. Neurological manifestations as primary presentation of COVID-19 in hospitalized patients. Acta Neurol Scand. 2021;143(5):569-74. https://doi.org/10. 1111/ane.13399.

140. Amanat M, Rezaei N, Roozbeh M, et al. Neurological manifestations as the predictors of severity and mortality in hospitalized individuals with COVID-19: a multicenter prospective clinical study. BMC Neurol. 2021;21 (1):116. https://doi.org/10.1186/s12883-021-02152-5 (Published 2021 Mar 16).

141 Fan S, Xiao M, Han F, et al. Neurological manifestations in critically ill patients with COVID-19: a retrospective study. Front Neurol. 2020;11:806. https://doi.org/10.3389/fneur.2020.00806 (Published 2020 Jul 10).

142. Travi G, Rossotti R, Merli M, et al. Neurological manifestations in patients hospitalized with COVID-19: A retrospective analysis from a large cohort in Northern Italy. Eur J Neurosci. 2021;53(8):2912-22. https://doi.org/10. 1111/ejn.15159.

143. Yuksel H, Gursoy GT, Dirik EB, et al. Neurological manifestations of COVID-19 in confirmed and probable cases: a descriptive study from a large tertiary care center. J Clin Neurosci. 2021;86:97-102. https://doi. org/10.1016/j.jocn.2021.01.002.
144 Rass V, Beer R, Schiefecker AJ, et al. Neurological outcome and quality of life 3 months after COVID-19: a prospective observational cohort study. Eur J Neurol. 2021. https://doi.org/10.1111/ene.14803 (published online ahead of print, 2021 Mar 7).

145. Carcamo Garcia MH, Garcia Choza DD, Salazar Linares BJ, Diaz MM. Neurological manifestations of patients with mild-to-moderate COVID19 attending a public hospital in Lima. Peru eNeurologicalSci. 2021;23: 100338. https://doi.org/10.1016/j.ensci.2021.100338.

146. García-Moncó JC, Cabrera-Muras A, Collía-Fernández A, et al. Neurological reasons for consultation and hospitalization during the COVID-19 pandemic. Neurol Sci. 2020;41(11):3031-8. https://doi.org/10.1007/ s10072-020-04714-w.

147. García-Azorín D, Abildúa MJA, Aguirre MEE, et al. Neurological presentations of COVID-19: findings from the Spanish Society of Neurology neuroCOVID-19 registry. J Neurol Sci. 2021;423: 117283. https://doi.org/ 10.1016/j.jns.2020.117283.

148. García-Azorín D, Trigo J, Martínez-Pías E, et al. Neurological symptoms in Covid-19 patients in the emergency department. Brain Behav. 2021;11(4): e02058. https://doi.org/10.1002/brb3.2058.

149 Ermis U, Rust MI, Bungenberg J, et al. Neurological symptoms in COVID19: a cross-sectional monocentric study of hospitalized patients. Neurol Res Pract. 2021;3(1):17. https://doi.org/10.1186/s42466-021-00116-1

\section{(Published 2021 Mar 12}

150. Giorgianni A, Vinacci G, Agosti E, Mercuri A, Baruzzi F. Neuroradiological features in COVID-19 patients: first evidence in a complex scenario. J Neuroradiol. 2020;47(6):474-6. https://doi.org/10.1016/j.neurad.2020. 05.005 .

151. Patel A, Charani E, Ariyanayagam D, et al. New-onset anosmia and ageusia in adult patients diagnosed with SARS-CoV-2 infection. Clin Microbiol Infect. 2020;26(9):1236-41. https://doi.org/10.1016/j.cmi. 2020.05.026.

152. Mirfazeli FS, Sarabi-Jamab A, Jahanbakhshi A, et al. Neuropsychiatric manifestations of COVID-19 can be clustered in three distinct symptom categories. Sci Rep. 2020;10(1):20957. https://doi.org/10.1038/s41598020-78050-6 (Published 2020 Dec 1).

153. Altin F, Cingi C, Uzun T, Bal C. Olfactory and gustatory abnormalities in COVID-19 cases. Eur Arch Otorhinolaryngol. 2020;277(10):2775-81. https://doi.org/10.1007/s00405-020-06155-9.

154. Ramasamy K, Saniasiaya J, Abdul GN. Olfactory and gustatory dysfunctions as a clinical manifestation of Coronavirus Disease 2019 in a Malaysian Tertiary Center. Ann Otol Rhinol Laryngol. 2021;130(5):513-9. https://doi.org/10.1177/0003489420963165.

155. Paderno A, Mattavelli D, Rampinelli V, et al. Olfactory and gustatory outcomes in COVID-19: a prospective evaluation in nonhospitalized subjects. Otolaryngol Head Neck Surg. 2020;163(6):1144-9. https://doi. org/10.1177/0194599820939538.

156. Speth MM, Singer-Cornelius T, Oberle M, Gengler I, Brockmeier SJ, Sedaghat AR. Olfactory dysfunction and sinonasal symptomatology in COVID-19: prevalence, severity, timing, and associated characteristics. Otolaryngol Head Neck Surg. 2020;163(1):114-20. https://doi.org/10. 1177/0194599820929185.

157 Thakur K, Sagayaraj A, Prasad KC, Gupta A. Olfactory dysfunction in COVID-19 patients: findings from a tertiary rural centre. Indian J Otolaryngol Head Neck Surg. 2021. https://doi.org/10.1007/ s12070-021-02364-8.

158. Özçelik Korkmaz M, Eğilmez OK, Özçelik MA, Güven M. Otolaryngological manifestations of hospitalised patients with confirmed COVID-19 infection. Eur Arch Otorhinolaryngol. 2021;278(5):1675-85. https://doi. org/10.1007/s00405-020-06396-8.

159. Elibol E. Otolaryngological symptoms in COVID-19. Eur Arch Otorhinolaryngol. 2021;278(4):1233-6. https://doi.org/10.1007/ s00405-020-06319-7.

160. Lechien JR, Cabaraux P, Chiesa-Estomba CM, et al. Objective olfactory evaluation of self-reported loss of smell in a case series of 86 COVID-19 patients. Head Neck. 2020;42(7):1583-90. https://doi.org/10.1002/hed. 26279.

161. O'Sullivan G, Jacob S, Barrett PM, Gallagher J. Covid-19 presentation among symptomatic healthcare workers in Ireland. Occup Med (Lond). 2021;71(2):95-8. https://doi.org/10.1093/occmed/kqab012.

162. Graham EL, Clark JR, Orban ZS, et al. Persistent neurologic symptoms and cognitive dysfunction in non-hospitalized Covid-19"long haulers." 
Ann Clin Transl Neurol. 2021;8(5):1073-85. https://doi.org/10.1002/acn3. 51350.

163 Gregorevic K, Maier A, Miranda R, et al. Presenting symptoms of COVID19 and clinical outcomes in hospitalised older adults. Intern Med J. 2021. https://doi.org/10.1111/imj.15286 (published online ahead of print, 2021 Mar 16).

164. Lv H, Zhang W, Zhu Z, et al. Prevalence and recovery time of olfactory and gustatory dysfunction in hospitalized patients with COVID-19 in Wuhan, China. Int J Infect Dis. 2020;100:507-12. https://doi.org/10. 1016/j.jiji.2020.09.039.

165. Nouchi A, Chastang J, Miyara M, et al. Prevalence of hyposmia and hypogeusia in 390 COVID-19 hospitalized patients and outpatients: a cross-sectional study. Eur J Clin Microbiol Infect Dis. 2021;40(4):691-7. https://doi.org/10.1007/s10096-020-04056-7.

166. Shahjouei S, Tsivgoulis G, Farahmand G, et al. SARS-CoV-2 and stroke characteristics: a report from the multinational COVID-19 stroke study group. Stroke. 2021;52(5):e117-30. https://doi.org/10.1161/STROKEAHA. 120.032927.

167. Bustos P, Tambley C, Acevedo A, et al. Quantitative detection of SARSCoV-2 RNA in nasopharyngeal samples from infected patients with mild disease. J Med Virol. 2021;93(4):2439-45. https://doi.org/10.1002/ jmv.26761.

168. Mubaraki AA, Alrbaiai GT, Sibyani AK, Alhulayfi RM, Alzaidi RS, Almalki HS. Prevalence of anosmia among COVID-19 patients in Taif City, Kingdom of Saudi Arabia. Saudi Med J. 2021;42(1):38-43. https://doi.org/10. 15537/smj.2021.1.25588.

169. Salepci E, Turk B, Ozcan SN, et al. Symptomatology of COVID-19 from the otorhinolaryngology perspective: a survey of 223 SARS-CoV-2 RNA-positive patients. Eur Arch Otorhinolaryngol. 2021;278(2):525-35. https://doi.org/10.1007/s00405-020-06284-1.

170. Zhang J, Wang $X$, Jia $X$, et al. Risk factors for disease severity, unimprovement, and mortality in COVID-19 patients in Wuhan, China. Clin Microbiol Infect. 2020;26(6):767-72. https://doi.org/10.1016/j.cmi.2020. 04.012.

171. Paderno A, Schreiber A, Grammatica A, et al. Smell and taste alterations in COVID-19: a cross-sectional analysis of different cohorts. Int Forum Allergy Rhinol. 2020;10(8):955-62. https://doi.org/10.1002/alr.22610.

172. Izquierdo-Domínguez A, Rojas-Lechuga MJ, Chiesa-Estomba C, et al. Smell and taste dysfunction in COVID-19 is associated with younger age in ambulatory settings: a multicenter cross-sectional study. J Investig Allergol Clin Immunol. 2020;30(5):346-57. https://doi.org/10.18176/ jiaci.0595.

173. Tostmann A, Bradley J, Bousema T, et al. Strong associations and moderate predictive value of early symptoms for SARS-CoV-2 test positivity among healthcare workers, the Netherlands, March 2020. Euro Surveill. 2020;25(16):2000508. https://doi.org/10.2807/1560-7917.ES.2020.25.16. 2000508.

174. Barillari MR, Bastiani L, Lechien JR, et al. A structural equation model to examine the clinical features of mild-to-moderate COVID-19: a multicenter Italian study. J Med Virol. 2021;93(2):983-94. https://doi.org/10. 1002/jmv.26354.

175. Ninchritz-Becerra E, Soriano-Reixach MM, Mayo-Yánez M, et al. Subjective evaluation of smell and taste dysfunction in patients with mild COVID-19 in Spain. Evaluación subjetiva de las alteraciones del olfato y del gusto en pacientes con afectación leve por COVID-19 en España. Med Clin (Barc). 2021;156(2):61-4. https://doi.org/10.1016/j.medcli. 2020.08.004.

176. Dixon BE, Wools-Kaloustian K, Fadel WF, et al. Symptoms and symptom clusters associated with SARS-CoV-2 infection in community-based populations: results from a statewide epidemiological study. Preprint. medRxiv. 2020. https://doi.org/10.1101/2020.10.11.20210922 (Published 2020 Oct 22).

177. Khedr EM, Abo-Elfetoh N, Deaf E, et al. Surveillance study of acute neurological manifestations among 439 Egyptian patients with COVID19 in Assiut and Aswan University Hospitals. Neuroepidemiology. 2021:55(2):109-18. https://doi.org/10.1159/000513647.

178. Sayın P, Altınay M, CInar AS, Ozdemir HM. Taste and smell impairment in critically ill patients with COVID-19: an intensive care unit study. Ear Nose Throat J. 2021;100(2_suppl):174S-179S. https://doi.org/10.1177/ 0145561320977464.
179. Chow EJ, Schwartz NG, Tobolowsky FA, et al. Symptom screening at illness onset of health care personnel with SARS-CoV-2 infection in King County, Washington. JAMA. 2020;323(20):2087-9. https://doi.org/10. 1001/jama.2020.6637.

180. Altunisik E, Sayiner HS, Aksoz S, Cil E, Ozgenc G. Neurological symptoms in COVID-19 patients. Bratisl Lek Listy. 2021;122(1):39-44. https://doi. org/10.4149/BLL_2021_004.

181. Iadecola C, Anrather J, Kamel H. Effects of COVID-19 on the nervous system. Cell. 2020;183(1):16-27.e1. https://doi.org/10.1016/j.cell.2020.08. 028.

182. Wang Q, Zhang Y, Wu L, et al. Structural and functional basis of SARSCoV-2 entry by using human ACE2. Cell. 2020;181(4):894-904.e9. https://doi.org/10.1016/j.cell.2020.03.045.

183 Generoso JS, Barichello de Quevedo JL, Cattani M, et al. Neurobiology of COVID-19: how can the virus affect the brain. Braz J Psychiatry. 2021. https://doi.org/10.1590/1516-4446-2020-1488 (published online ahead of print, 2021 Feb 10).

184. Xia H, Lazartiques E. Angiotensin-converting enzyme 2 in the brain: properties and future directions. J Neurochem. 2008;107(6):1482-94. https://doi.org/10.1111/j.1471-4159.2008.05723.x.

185. Wu Y, Xu X, Chen Z, et al. Nervous system involvement after infection with COVID-19 and other coronaviruses. Brain Behav Immun. 2020;87:18-22. https://doi.org/10.1016/j.bbi.2020.03.031.

186. Gasmi A, Tippairote T, Mujawdiya PK, et al. Neurological Involvements of SARS-CoV2 Infection. Mol Neurobiol. 2021;58(3):944-9. https://doi.org/ 10.1007/s12035-020-02070-6.

187. Elmashala A, Chopra S, Garg A. The neurologic manifestations of coronavirus disease 2019. J Neurol Res. 2020;10(4):107-12. https://doi.org/ 10.14740/jnr603.

188. Fotuhi M, Mian A, Meysami S, Raji CA. Neurobiology of COVID-19. J Alzheimers Dis. 2020;76(1):3-19. https://doi.org/10.3233/JAD-200581.

189. Cabello-Verrugio C, Morales MG, Rivera JC, Cabrera D, Simon F. Reninangiotensin system: an old player with novel functions in skeletal muscle. Med Res Rev. 2015;35(3):437-63. https://doi.org/10.1002/med. 21343.

190. Bagheri SH, Asghari A, Farhadi M, et al. Coincidence of COVID-19 epidemic and olfactory dysfunction outbreak in Iran. Med J Islam Repub Iran. 2020;34:62. https://doi.org/10.34171/mjiri.34.62 (Published 2020 Jun 15).

191. Kim MS, Lee GH, Kim YM, et al. Angiotensin II causes apoptosis of adult hippocampal neural stem cells and memory impairment through the action on AMPK-PGC1 a signaling in heart failure. Stem Cells Transl Med. 2017;6(6):1491-503. https://doi.org/10.1002/sctm.16-0382.

192. Fagre A, Lewis J, Eckley M, et al. SARS-CoV-2 infection, neuropathogenesis and transmission among deer mice: Implications for reverse zoonosis to New World rodents. Preprint. bioRxiv. 2020. https://doi.org/ 10.1101/2020.08.07.241810 (Published 2020 Aug 7).

193. Lippi G, Wong J, Henry BM. Hypertension in patients with coronavirus disease 2019 (COVID-19): a pooled analysis. Pol Arch Intern Med. 2020;130(4):304-9. https://doi.org/10.20452/pamw.15272.

194. Soltani Zangbar H, Gorji A, Ghadiri T. A review on the neurological manifestations of COVID-19 infection: a mechanistic view. Mol Neurobiol. 2021:58(2):536-49. https://doi.org/10.1007/s12035-020-02149-0.

195. Zhang C, Shi L, Wang FS. Liver injury in COVID-19: management and challenges. Lancet Gastroenterol Hepatol. 2020;5(5):428-30. https://doi. org/10.1016/S2468-1253(20)30057-1.

196 Chen R, Wang K, Yu J, et al. The spatial and cell-type distribution of SARS-CoV-2 receptor ACE2 in the human and mouse brains. Front Neurol. 2021;1 1: 573095. https://doi.org/10.3389/fneur.2020.573095.

197. Cheng Y, Luo R, Wang K, et al. Kidney disease is associated with in-hospital death of patients with COVID-19. Kidney Int. 2020;97(5):829-38. https://doi.org/10.1016/j.kint.2020.03.005.

198. Li G, Fan Y, Lai Y, et al. Coronavirus infections and immune responses. $J$ Med Virol. 2020;92(4):424-32. https://doi.org/10.1002/jmv.25685.

199. Davis LE, Koster F, Cawthon A. Neurologic aspects of influenza viruses. Handb Clin Neurol. 2014;123:619-45. https://doi.org/10.1016/B978-0444-53488-0.00030-4.

200. Mehta P, McAuley DF, Brown M, et al. COVID-19: consider cytokine storm syndromes and immunosuppression. Lancet. 2020;395(10229):1033-4. https://doi.org/10.1016/S0140-6736(20) 30628-0. 
201. Steardo L, Steardo L Jr, Zorec R, Verkhratsky A. Neuroinfection may contribute to pathophysiology and clinical manifestations of COVID-19. Acta Physiol (Oxf). 2020;229(3): e13473. https://doi.org/10.1111/apha. 13473.

202. Nathaniel TI, Williams-Hernandez A, Hunter AL, et al. Tissue hypoxia during ischemic stroke: adaptive clues from hypoxia-tolerant animal models. Brain Res Bull. 2015;114:1-12. https://doi.org/10.1016/j.brain resbull.2015.02.006.

203. Dhama K, Sharun K, Tiwari R, et al. COVID-19, an emerging coronavirus infection: advances and prospects in designing and developing vaccines, immunotherapeutics, and therapeutics. Hum Vaccin Immunother. 2020;16(6):1232-8. https://doi.org/10.1080/21645515.2020. 1735227.

204. Boopathi S, Poma AB, Kolandaivel P. Novel 2019 coronavirus structure, mechanism of action, antiviral drug promises and rule out against its treatment. J Biomol Struct Dyn. 2021;39(9):3409-18. https://doi.org/10. 1080/07391102.2020.1758788

205. Dalakas MC. Guillain-Barré syndrome: the first documented COVID19-triggered autoimmune neurologic disease: more to come with myositis in the offing. Neurol Neuroimmunol Neuroinflamm. 2020;7(5): e781. https://doi.org/10.1212/NXI.0000000000000781 (Published 2020 Jun 9).

206. Virhammar J, Nääs A, Fällmar D, et al. Biomarkers for central nervous system injury in cerebrospinal fluid are elevated in COVID-19 and associated with neurological symptoms and disease severity. Eur J Neurol. 2020. https://doi.org/10.1111/ene.14703 (published online ahead of print, 2020 Dec 28).

207. Tiwari A, Berekashvili K, Vulkanov V, et al. Etiologic subtypes of ischemic stroke in SARS-CoV-2 patients in a cohort of New York City Hospitals. Front Neurol. 2020;11:1004. https://doi.org/10.3389/fneur.2020.01004 (Published 2020 Sep 17).

208 Yaghi S, Ishida K, Torres J, et al. SARS-CoV-2 and stroke in a New York healthcare system. Stroke. 2020;51(7):2002-11. https://doi.org/10.1161/ STROKEAHA.120.030335 (published correction appears in Stroke. 2020 Aug;51(8):e179).

209. Avula A, Nalleballe K, Narula N, et al. COVID-19 presenting as stroke. Brain Behav Immun. 2020;87:115-9. https://doi.org/10.1016/j.bbi.2020 04.077.

210. Millán M, Sobrino T, Arenillas JF, et al. Biological signatures of brain damage associated with high serum ferritin levels in patients with acute ischemic stroke and thrombolytic treatment. Dis Markers. 2008;25(3):181-8. https://doi.org/10.1155/2008/380356.

211. Cazzolla AP, Lovero R, Lo Muzio L, et al. Taste and smell disorders in COVID-19 patients: role of interleukin-6. ACS Chem Neurosci. 2020;11(17):2774-81. https://doi.org/10.1021/acschemneuro.0c00447.
212. Sutter R, Hert L, De Marchis GM, et al. Serum neurofilament light chain levels in the intensive care unit: comparison between severely ill patients with and without coronavirus disease 2019. Ann Neurol. 2021;89(3):610-6. https://doi.org/10.1002/ana.26004.

213. Lu Y, Li X, Geng D, et al. Cerebral micro-structural changes in COVID-19 patients - an MRI-based 3-month follow-up study. EClinicalMedicine. 2020;25: 100484. https://doi.org/10.1016/j.eclinm.2020.100484.

214 Moonis G, Filippi CG, Kirsch CFE, et al. The spectrum of neuroimaging findings on CT and MRI in adults with coronavirus disease (COVID-19). AJR Am J Roentgenol. 2020. https://doi.org/10.2214/AJR.20.24839 (published online ahead of print, 2020 Nov 25).

215 Zafar S, Aydemir S, Karceski S, et al. COVID-19 continuous-EEG case series: a descriptive study. J Clin Neurophysiol. 2021. https://doi.org/ 10.1097/WNP.0000000000000832 (published online ahead of print, 2021 Feb 16)

216. Wu C, Chen X, Cai Y, et al. Risk factors associated with acute respiratory distress syndrome and death in patients with coronavirus disease 2019 pneumonia in Wuhan, China. JAMA Intern Med. 2020;180(7):934-43. https://doi.org/10.1001/jamainternmed.2020.0994 (published correction appears in JAMA Intern Med. 2020 Jul 1;180(7):1031).

217. Jiang RD, Liu MQ, Chen Y, et al. Pathogenesis of SARS-CoV-2 in transgenic mice expressing human angiotensin-converting enzyme 2. Cell. 2020;182(1):50-58.e8. https://doi.org/10.1016/j.cell.2020.05.027.

218. Nath A. Neurologic complications of coronavirus infections. Neurology. 2020;94(19):809-10. https://doi.org/10.1212/WNL.0000000000009455.

219. Coraci D, Fusco A, Frizziero A, Giovannini S, Biscotti L, Padua L. Global approaches for global challenges: the possible support of rehabilitation in the management of COVID-19. J Med Virol. 2020;92(10):1739-40. https://doi.org/10.1002/jmv.25829.

220. Fridman S, Bres Bullrich M, Jimenez-Ruiz A, et al. Stroke risk, phenotypes, and death in COVID-19: systematic review and newly reported cases. Neurology. 2020;95(24):e3373-85. https://doi.org/10.1212/WNL. 0000000000010851

221. Foster AM, Armstrong J, Buckley A, et al. Encouraging family engagement in the rehabilitation process: a rehabilitation provider's development of support strategies for family members of people with traumatic brain injury. Disabil Rehabil. 2012;34(22):1855-62. https://doi. org/10.3109/09638288.2012.670028.

\section{Publisher's Note}

Springer Nature remains neutral with regard to jurisdictional claims in published maps and institutional affiliations.
Ready to submit your research? Choose BMC and benefit from:

- fast, convenient online submission

- thorough peer review by experienced researchers in your field

- rapid publication on acceptance

- support for research data, including large and complex data types

- gold Open Access which fosters wider collaboration and increased citations

- maximum visibility for your research: over 100M website views per year

At BMC, research is always in progress.

Learn more biomedcentral.com/submissions 